\title{
Electrical Properties of Zinc-Kaolin Composites below its Percolation Threshold
}

\author{
Babalola, O.A* and Alabi, A.B \\ Department of Physics, University of Ilorin, Ilorin, Nigeria (*babalolaOA@gmail.com)
}

\begin{abstract}
In this paper, we present some electrical properties of the zinc-kaolin cermet resistors with zinc metal fillers below the percolation threshold. Rectangular cermet rods of dimensions $65 \mathrm{~mm}$ by $6.5 \mathrm{~mm}$ by $3.2 \mathrm{~mm}$ were produced in a mould with semi-dry the zinc/kaolin powder mixture which is compressed with a force of about $1.32 \times 10^{5} \mathrm{~N}$. Percolation threshold was found to be both a function of the metal-kaolin ceramic mixture and the annealing temperature. The percolation threshold for cermets annealed at 300 and $400^{\circ} \mathrm{C}$ is between 70 and $80 \%$ (vol.) while the cermets annealed at temperatures between 500 and $900^{\circ} \mathrm{C}$ is between 15 and $20 \%$ (vol.). The electrical conduction mechanism of the zinc-kaolin cermet below the percolation threshold is a mixture of both the hopping and the tunneling model with the hopping mechanism dominating. The temperature coefficient of resistance (TCR) is predominantly positive and large (30000$45000 \mathrm{ppmK}^{-1}$ ) when cermet temperature is below $100^{0} \mathrm{C}$. It is observed that changes in the measurement of TCR can be used to determine percolation threshold in cermets.
\end{abstract}

Keywords: Cermet, Percolation threshold, Electrical properties, Composite, Hopping and Tunneling.

\section{INTRODUCTION}

The development of materials with improved properties is required in fields like electroanalysis and preparation of supercapacitors, sensors and electrocatalysts - Hall and Lee (1990), Kanbara et al. (1987), Tsionsky et al. (1994) and Gun et al. (1995). Therefore the preparation of new conductive materials is an area of growing interest in electrochemical technology since there are diverse applications in which these materials are unavoidable. Additionally, many electrolytic processes use precious-metal-based electrodes. This makes necessary, for economic reasons, either the preparation of a thin coating or the dispersion of the metal on an appropriate conductive support.

The preparation of conductive metal-ceramic composites can be accomplished through different procedures (Kanbara et al. (1987), Tsionsky et al. (1994) and Alcaniz-Monge et al. (1998)) including:

i. Sol-gel method in which a metal powder is dispersed in sol-gel derived ceramics Tsionsky et al. (1994)

ii. Liquid-gas phase method - Alcaniz-Monge et al. (1998) 
iii. Sintering of metal-clay mixtures - Kanbara et al. (1987). A metal powder and clay are intimately mixed and, after pressing, are heated in an oven to temperatures between 1073 and $1273 \mathrm{~K}$.

The materials obtained through this last procedure are cheap and have an electrical conductivity similar to that of composites prepared by the other methods. The conductivity is appropriate for electrochemical applications (e.g. as electrocatalyst support).

Although in the above study Alcaniz-Monge et al. (1998) the synthesis and characterisation of the composites from chemical and electrochemical points of view was discussed, the work did not go into the effect of the heat treatment temperature, structure of the ceramic and feasibility of these composites in the preparation of electrocatalysts.

The percolation threshold is defined as the minimal concentration (volume fraction, $\mathrm{V}_{\text {crit }}$ ) of the conducting filler at which a continuous conducting chain of macroscopic length appears in the system (Ponomarenko et al., 1990). Sherman et al. (1983) described percolation threshold as the point at which a macroscopic length of continuous chain is first formed.

There have been several attempts to model the percolation phenomenon. The fraction of the filler required to achieve percolation can be modelled by the Monte Carlo method -Jacoboni et al. (1981) and Jacoboni et al. (1983), the effective medium theory-Mantese (1986) and the Anderson model -Marko (2000). The essence of the percolation theory itself is to determine how a given set of conducting sites, regularly or randomly positioned in some space is interconnected. Most of the research works involving cermets have been on their electrical properties above the percolation threshold. The main objective of this paper is thus to gain an insight into the electrical properties of the zinc-kaolin cermet below its percolation threshold such as electrical conduction mechanism, variation of TCR with cermets temperature, variation of conductivity with annealing temperature and variation of cermets resistance with annealing time.

\section{EXPERIMENTAL}

The zinc-clay cermet consists of three main components namely the zinc powder, which serves as the conducting filler, clay powder which serves as the insulating matrix and a few drops of sodium silicate $\mathrm{Na}_{2} \mathrm{SO}_{4}$ which serves as the binder. 
The zinc powder was manufactured by Griffin and George, Bishop Meadow Road, Fisons Plc Scientific Equipment Division, England. It has a purity of about $99.9 \%$ zinc. Other impurities include: $\mathrm{Cu} \sim 0.01 \%, \mathrm{Fe} \sim 0.01 \%, \mathrm{~Pb} \sim 0.8 \%$ and $\mathrm{Sn} \sim 0.03 \%$.

The kaolinite clay was obtained from a commercial source in Ilorin, Nigeria. It was thoroughly washed in water and the clay-water suspension was then filtered to remove all lumps. The filtered suspension was put in a cotton bag and then hung in air for several days until most of the water has evaporated. The clay thus obtained was then sun-dried and ground into a fine powder. Sodium silicate solution (100 $\mathrm{g}$ of the solid $\mathrm{Na}_{2} \mathrm{SiO}_{4}$ was dissolved in $50 \mathrm{cl}$ of hot water) was used as a blinder for the cermets. A maximum of 2-3 drops were added to the cermet powder before compaction. It is important that the cermet powder be semi-dry so that it does not flow under high pressure.

We produced rectangular cermet rods of dimensions $65 \mathrm{~mm}$ by $6.5 \mathrm{~mm}$ by $3.2 \mathrm{~mm}$ in a mould for which the powder is compressed with a force of about $1.32 \times 10^{5} \mathrm{~N}$. This force was used to mould the entire resistor set.

The four cermet rodseach were produced with zinc powder content varying from $1 \%$ (vol.) up to $30 \%$ (vol.) in increasing steps of $1 \%$ (vol.) (below percolation threshold). For studies above the percolation threshold, we produce cermets with filler contents ranging between 30 and 95\% (vol.), in steps of $5 \%$ (vol.). All the cermet rods were fired in an electric oven (Vecstar furnace) at annealing temperatures between 300 and $1000^{\circ} \mathrm{C}$ for a time duration of 1 hour and at each stage, measurements of electrical properties were made.

\section{RESULTS AND DISCUSSION}

\subsection{Variation of Percolation threshold with Annealing Temperature}

The variation of conductivity with the relative percentage of conducting filler is an important characteristic of any composite system since it describes how easily the systems can be controlled. When the conductive phase is high enough so that there exists particle to particle contact of the filler, the resistor is said to be operating above the percolation threshold.

Ponomarenko et al. (1990) and Sherman et al. (1983) defined percolation threshold as the minimum filler concentration of which a continuous chain of macroscopic length appears in the system. At percolation threshold, a sudden change in conductivity is expected. 
Figure1 show the variation of conductivity with increase in filler concentration for cermets annealed at temperatures between $300^{\circ} \mathrm{C}$ and the maximum range in the experiment for a duration of one hour each.

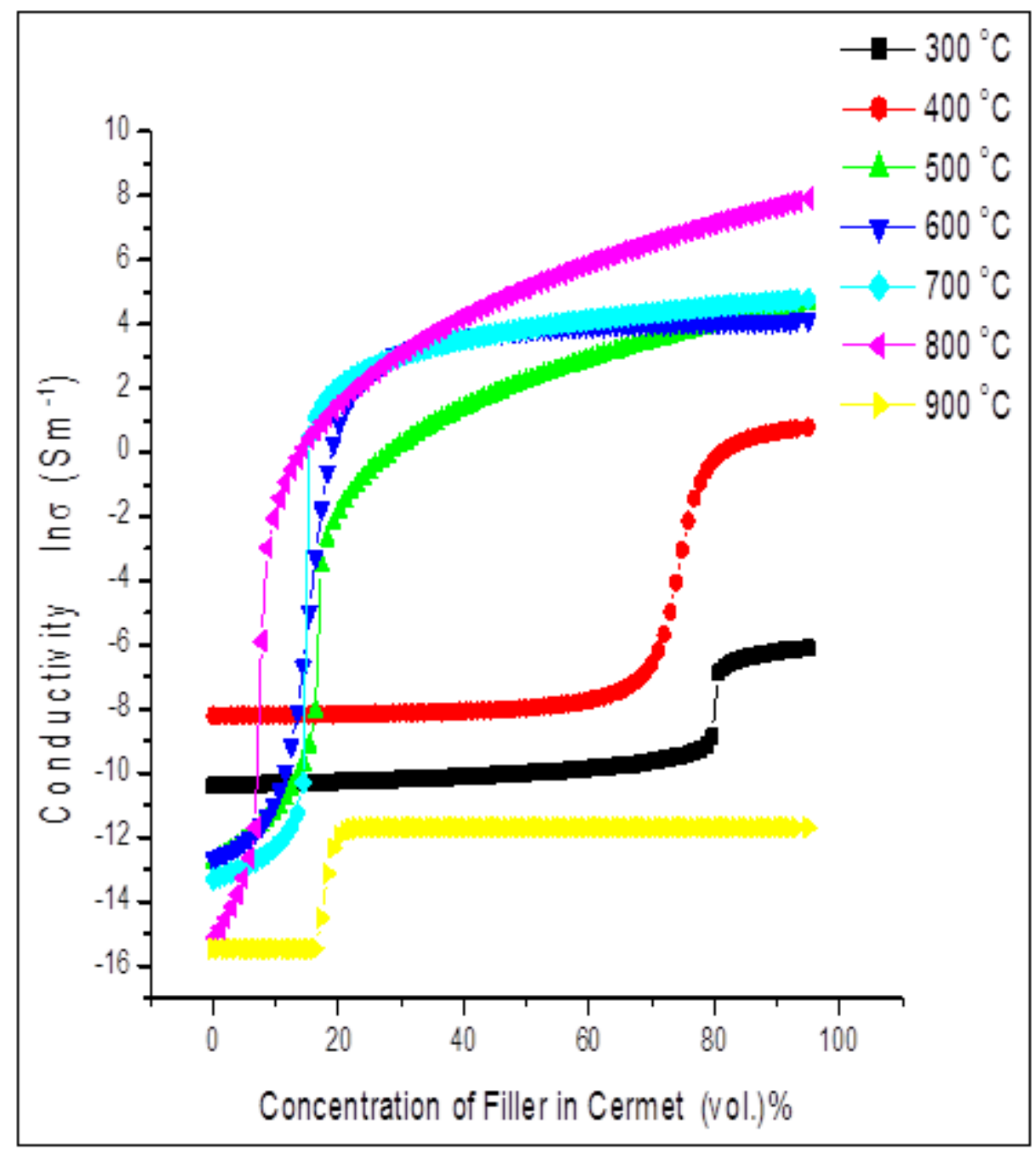

Figure 1. Variation of conductivity with $\mathrm{Zn}$ concentration for Cermets annealed at 300 to $900^{\circ} \mathrm{C}$.

Two phases of percolation can be observed in the Zinc-Kaolin cermet because of annealing. The first phase occurs when the annealing temperature is $300^{\circ} \mathrm{C}$ and $400^{\circ} \mathrm{C}$ while the second phase occurs when the annealing temperature is between $500^{\circ} \mathrm{C}$ and $900^{\circ} \mathrm{C}$. It can be seen that percolation threshold (defined by the zinc filler concentration where a sudden and large change in conductivity occurs in the plot of conductivity versus filler concentration) is high (70-80\% (vol.) $\mathrm{Zn}$ ) for cermets annealed at temperatures of $300^{\circ} \mathrm{C}$ and $400^{\circ} \mathrm{C}$. With the exception of the (C) CNCS, Mekelle University

ISSN:2220-184X 
cermets annealed at $800^{\circ} \mathrm{C}$ which has the lowest percolation threshold of about $7.5 \%$ (vol.) $\mathrm{Zn}$, the percolation threshold for cermets annealed at temperatures between $\mathrm{T}_{\mathrm{f}}=500^{\circ} \mathrm{C}$ and $900^{\circ} \mathrm{C}$ is found to be between 15 and $20 \%$ (vol.) $\mathrm{Zn}$.

Percolation of metal-insulator regime is usually found to be in the neighbourhood of 40 to $55 \%$ (vol.) according to Marko (2000). However for the Zn-Kaolin cermet annealed at temperatures of $300^{\circ} \mathrm{C}$ and $400^{\circ} \mathrm{C}$, it is observed that the percolation threshold is much higher (70-80\% (vol.) $\mathrm{Zn}$ ). This is attributed to the thin oxide coating on the $\mathrm{Zn}$ particles since zinc is readily oxidized. This oxide presents a high resistance between zinc-zinc particles in contact with one another within the cermet structure at percolation threshold. Hence conductivity is enhanced only when the density of zinc-zinc particle contact increase appreciably i.e. in the filler concentration of between $70-80 \%$ (vol.) $\mathrm{Zn}$.

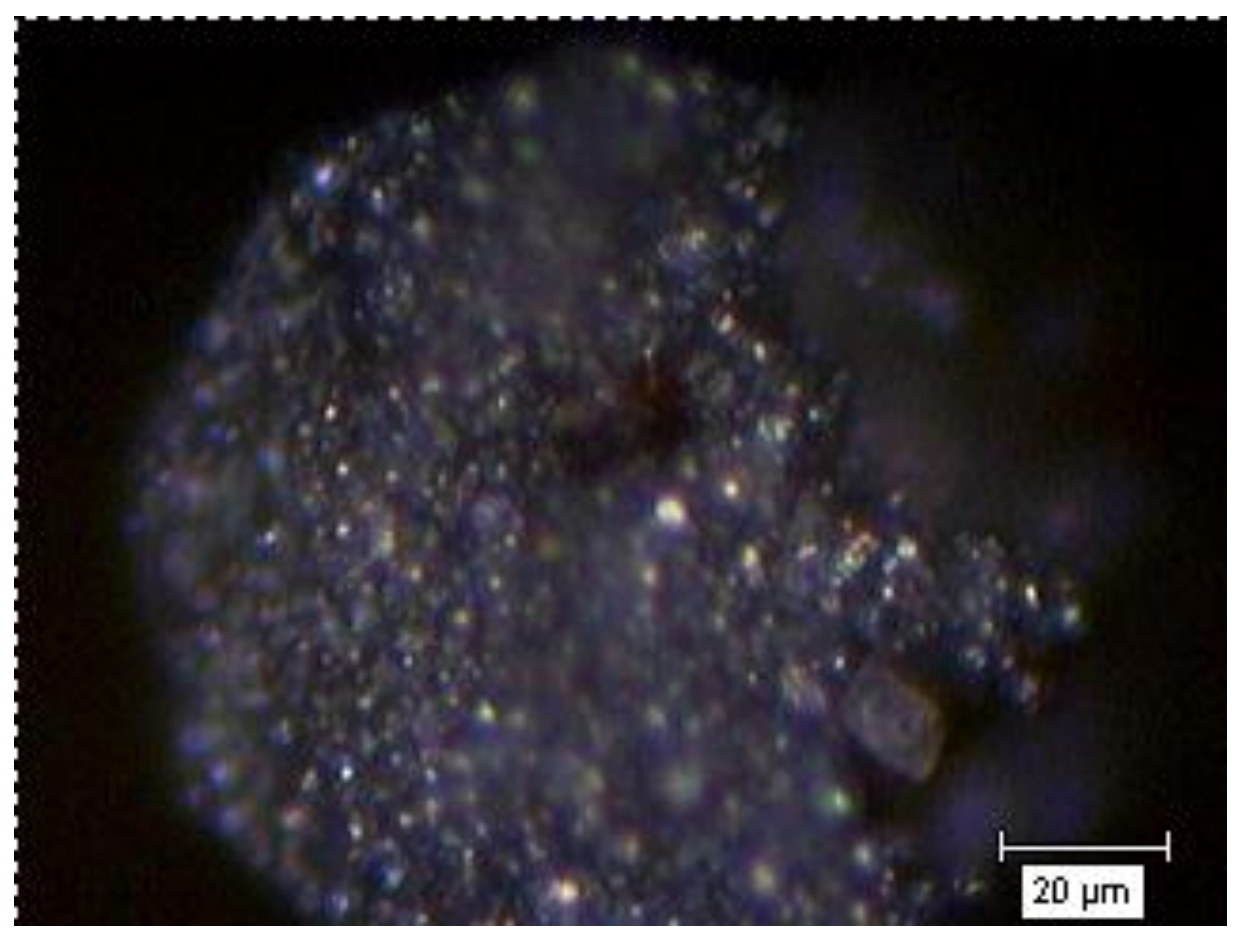

Figure 2. Photomicrographs of Zn-clay Cermets containing $70 \%$ (vol.) $\mathrm{Zn}$ and annealed at $300^{\circ} \mathrm{C}$ showing the spherical nature of the zinc filler.

The low percolation threshold obtained for cermets annealed at temperatures between $\mathrm{T}_{\mathrm{f}}=500^{0} \mathrm{C}$ and $900^{\circ} \mathrm{C}$ is due to the fact that the spherical nature of the zinc powder has been changed to a fibre-like orientation within the cermet due to the melting point of the zinc being exceeded during annealing. The melting point of zinc is $367^{\circ} \mathrm{C}$ such that during annealing, the spherical 
zinc powder melts and flows through micro-pores within the cermet structure to link up with one another and produce a low cermet resistance. Ponomarenko et al. (1990) has shown that percolation threshold of cermets with filler fibre is significantly much lower than that of the cermets with spherical fillers. The zinc fibres have diameters ranging between 0.1 to $2 \mu \mathrm{m}$. The spherical and fibre nature of the zinc in the cermets annealed at $300^{\circ} \mathrm{C}$ and $700^{\circ} \mathrm{C}$ are presented in figures 2 and 3.

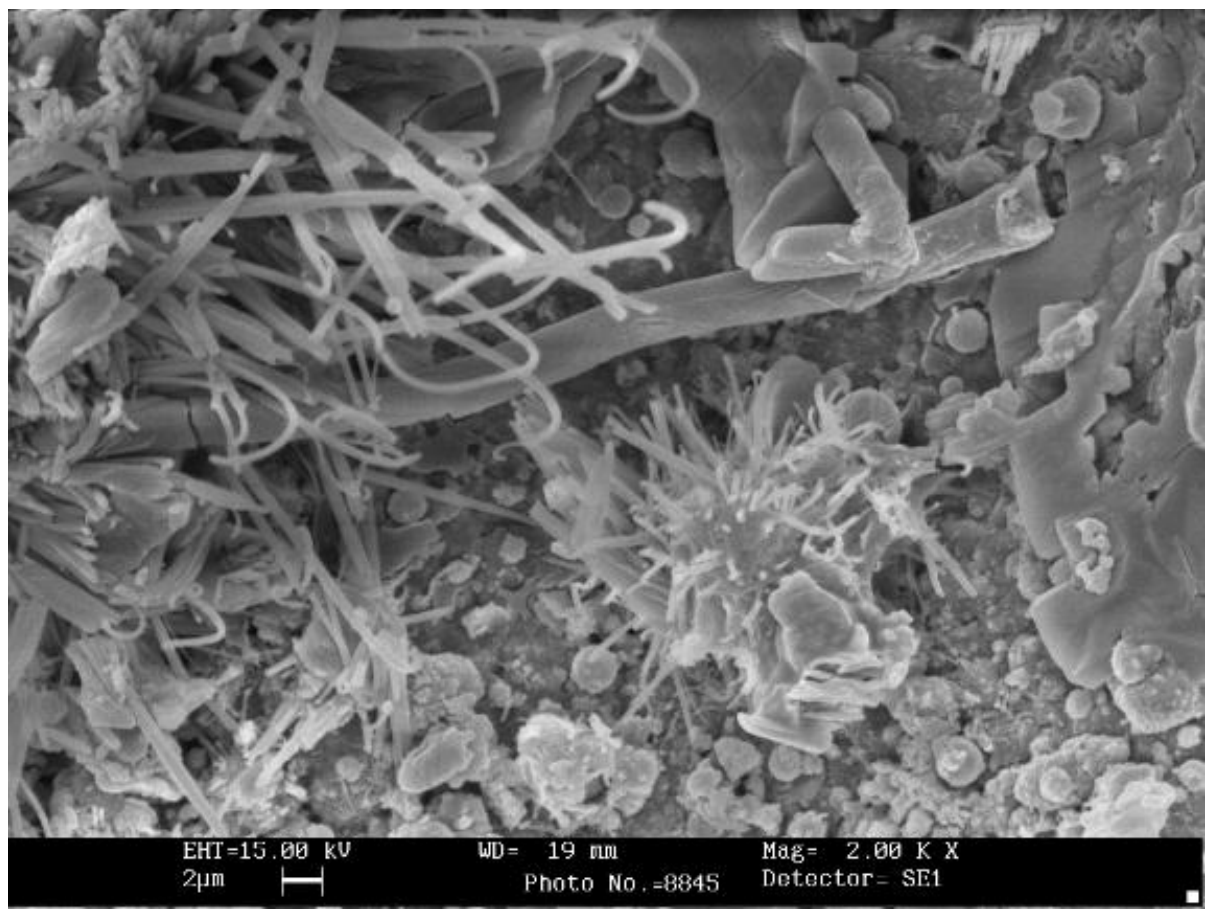

Figure 3. SEM micrographs of zinc-clay cermet containing $70 \%$ (vol.) $\mathrm{Zn}$ and annealed at $700^{\circ} \mathrm{C}$ Viewed at $\mathrm{x} 2000$.

\subsection{Conduction Mechanism of Zn:kaolin Cermet}

Abe and Taketa (1991), Pike and Seager (1977), and Okutan et al. (2005) have shown that conduction in cermets could be modelled after:

i. Amorphous model:

$$
\sigma=\sigma_{o} \exp \left(-\frac{E_{a}}{k T}\right)
$$

ii. Hopping conduction model:

$$
R=R_{o} T^{1 / 2} \exp \left(\frac{T_{o}}{T}\right)^{1 / 4}
$$


iii. Tunnelling model:

$$
R=\frac{1}{2} R_{b o}\left(\frac{\sin a T}{b T}\right)\left[1+\exp \left(\frac{E}{k T}\right)\right]+R_{m o}(1+b T)
$$

or the

iv. Conductive chain model:

$$
\sigma_{c}=\sigma_{f}\left[v_{f}-v_{c r i t}\right]^{t}
$$

Where, $\mathrm{R}_{\mathrm{mo}}$ is the resistance of the conductive particles, $a$ is the height of the tunnelling barrier, $\mathrm{b}$ is the TCR of the conductive component, $\mathrm{T}_{\mathrm{o}}$ is a characteristic temperature of the conducting material, $R_{b o}$ is the resistance of the semi-infinite electrodes. The temperature dependence of conductivity $\sigma$, can be expressed by the Arrhenius equation

$$
\sigma=\sigma_{o} \exp \left(-\frac{E_{a}}{k T}\right)
$$

Where, $E_{a}$ is the Activation energy of conductivity, $k$ is the Boltzmann's constant, $T$ is the cermet temperature and $\sigma_{\mathrm{o}}$ is a pre-exponential factor depending on mobility of charge carriers Vilcakova (2000). Activation energy of conductivity is the minimum electrical energy required to initiate conduction in a material.

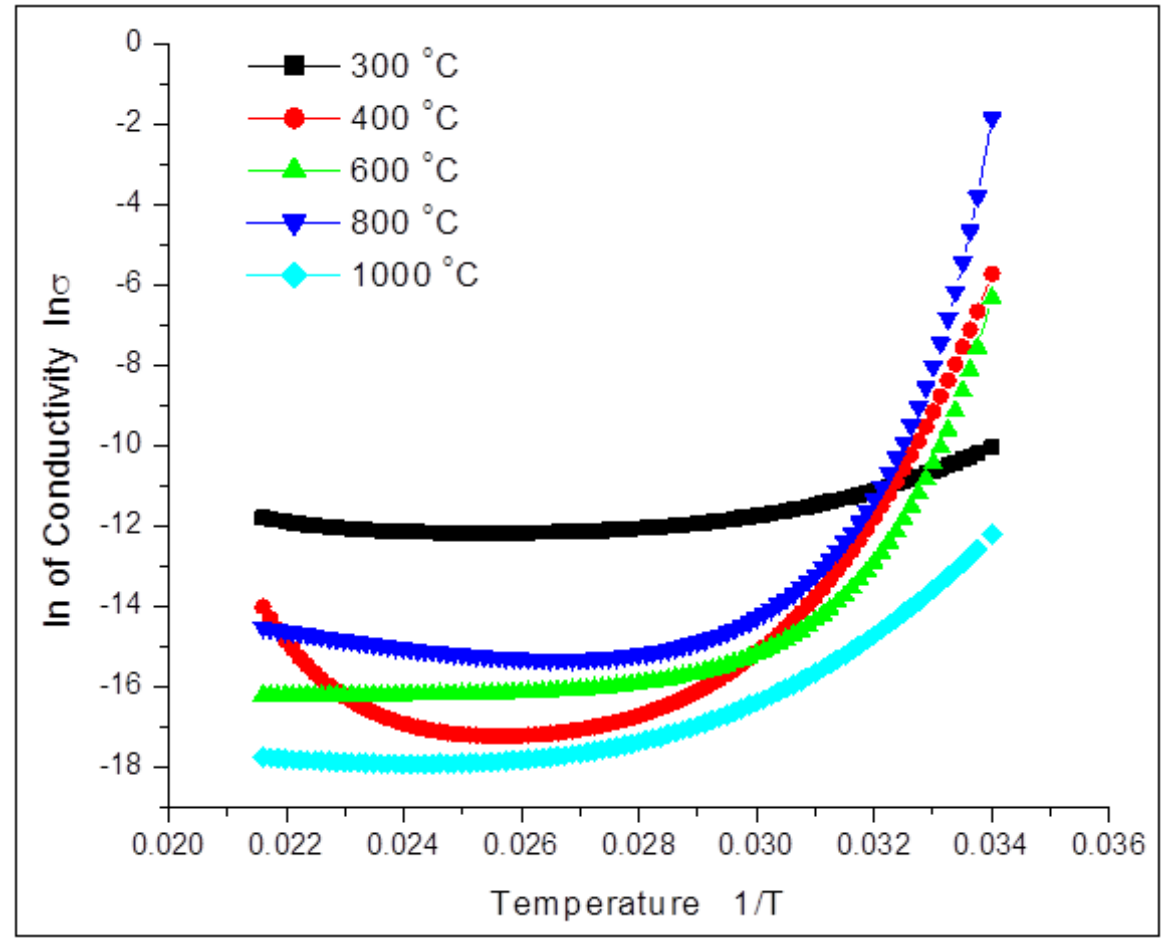

Figure 4. Plot of Cermet conductivity $\left(\log _{\mathrm{e}} \sigma\right)$ versus Cermet Temperature $(1 / \mathrm{T})$. 
Figure 4 shows the graph of the cermet conductivity $\left(\log _{\mathrm{e}} \sigma\right)$ against the cermets temperature $(1 / \mathrm{T})$. The curves show that the slopes of the curves are all positive. Applying the amorphous model, we observed that there is a breakdown of the equation because it is not possible to obtain negative activation energy in normal conductors. Hence we can infer that the predominant conduction mechanism is amorphous only for those activation energies where $\mathrm{E}_{\mathrm{a}}$ is positive and the conduction mechanism is hopping or tunnelling for regions where the activation energy is negative. A fit of the plot of $\left(\log _{\mathrm{e}} \sigma\right)$ versus $1 / \mathrm{T}$ shows that conduction mechanism is a mixture of both the hopping model and the tunneling model.

\subsection{Variation of cermets resistance with Annealing time for Cermets below the percolation threshold}

Plots of cermets resistance versus annealing time were produced for filler concentrations between 0 and 20\% (vol.) Zn. A typical result for the $5 \%$ (vol.) Zn : Kaolin cermets annealed at temperatures between $300^{\circ} \mathrm{C}$ and $1000^{\circ} \mathrm{C}$ is shown in Figures 5. It was observed that the cermets resistance reduced with increasing annealing time for all annealing temperature between $300^{\circ} \mathrm{C}$ and $1000^{\circ} \mathrm{C}$. However, beyond an annealing time of 60 minutes, the reduction of resistance was no more significant as all the graphs level off.

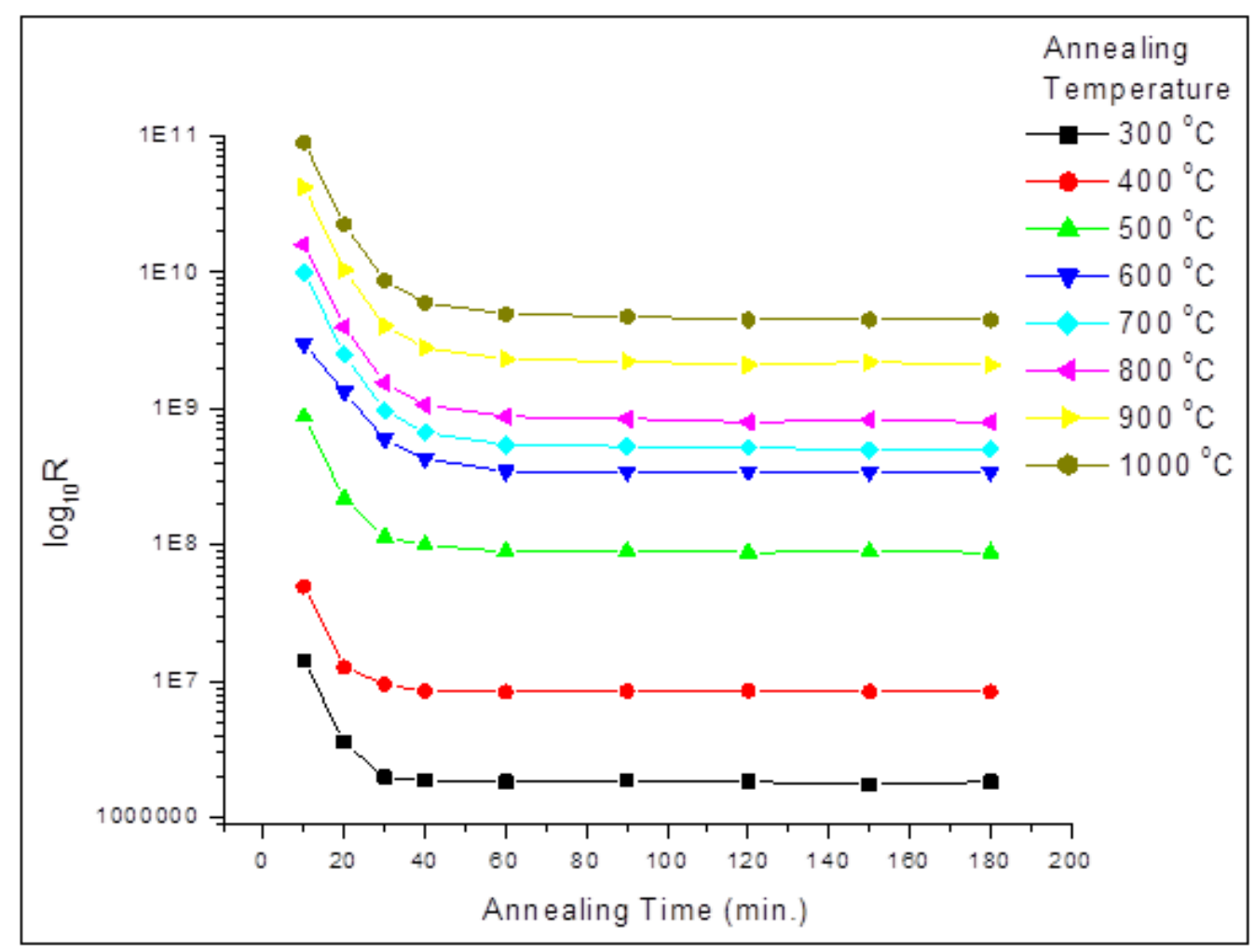

Figure 5. Variation of Cermets Resistance with annealing time for 5\% (vol.) Zn- Kaolin ratio. 
This shows that annealing is nearly completed at all these temperatures when the cermets have been soaked in the furnace for at least one-hour. This signifies that defects, burning-out of organic vehicles and of course sintering of individual particles in the cermet have occurred to an appreciable extent.

\subsection{Variation of TCR with Cermets Temperature}

The temperature coefficient of resistance of cermets is determined by the separate temperature coefficient of its constituents in their final form after firing modified by the effect of mechanical stress, inter-grain boundary effect, etc. Any effect, which varies the ratio of the components or stress built into the resistor during manufacture, is bound to affect the overall TCR.

The temperature coefficient of resistance of a material is generally defined as

$T C R=\frac{1}{R}\left(\frac{d R}{d T}\right) \times 10^{6} \quad p p m K^{-1}$

For most metals, $\frac{d R}{d T}$ is usually a constant over a wide temperature change, so that the TCR is approximated as

$T C R=\frac{1}{R}\left(\frac{R_{f}-R_{o}}{T_{f}-T_{i}}\right) \times 10^{6} \quad p p m K^{-1}$

In the case of the zinc-clay cermet however, $\frac{d R}{d T}$ is not a constant and it varies highly significantly with cermet temperature.

It can be observed that annealing temperatures, filler concentrations and cermet temperatures affect the overall TCR of the cermet. Figure 6 show the variation of TCR with cermet temperature. Below the percolation threshold where $v_{\mathrm{f}}<10 \%$ (vol.), TCR is predominantly positive and large when cermet temperature is below $100^{\circ} \mathrm{C}$. The positive TCR is found to reduce with increasing cermet temperature. Negative TCR occurs for cermets annealed at $300^{\circ} \mathrm{C}$ as a temperature of $120^{\circ} \mathrm{C}$ is exceeded and for cermets annealed at between 600 and $1000^{\circ} \mathrm{C}$, negative TCR occurs when a temperature of $160^{\circ} \mathrm{C}$ is exceeded. The positive TCR observed is most likely the result of potential barriers created at grain boundaries i.e. double layers at grain boundaries may constitute Schottkey barriers, which are similar in respect to those formed in voltage dependent resistors. This explanation is feasible because, it was also observed that the zinc-clay cermets also exhibit a strong voltage-dependence of resistivity. 


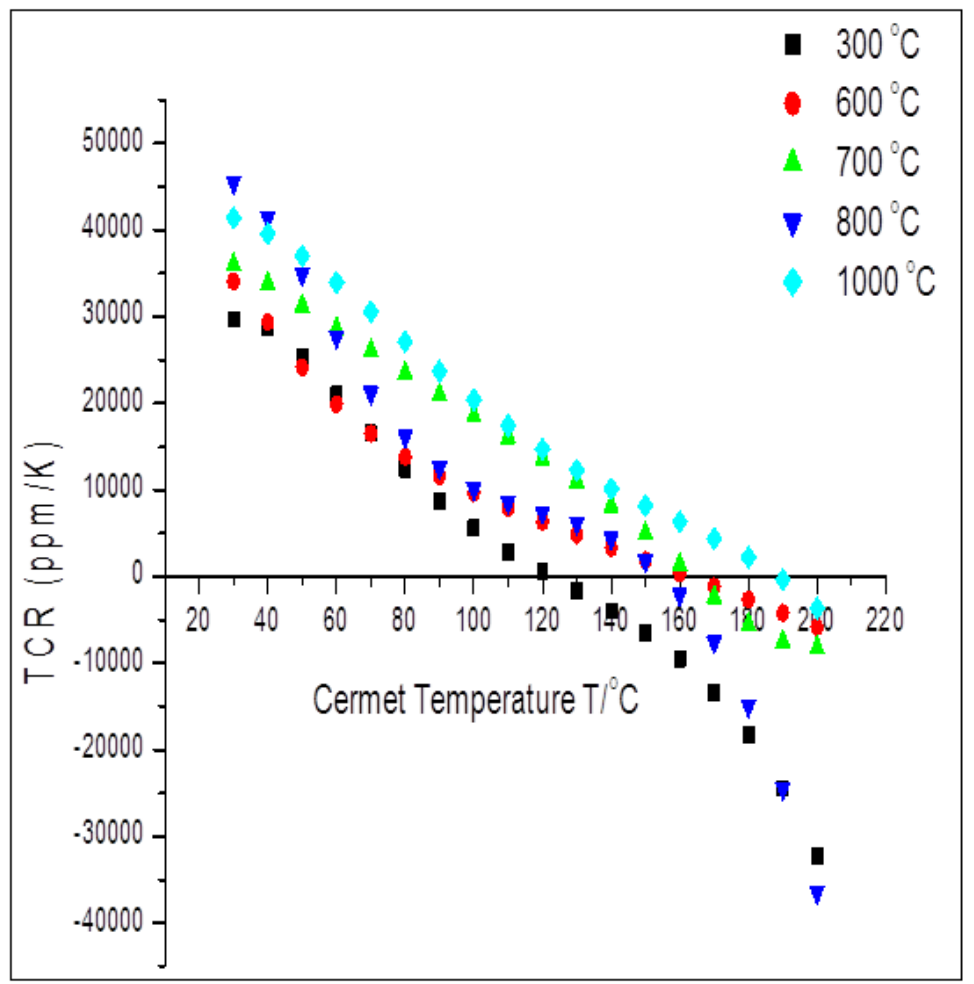

Figure 6. Variation of Temperature Coefficient of Resistance versus Cermet Temperature for 7\% (vol.) Zn filler Content.

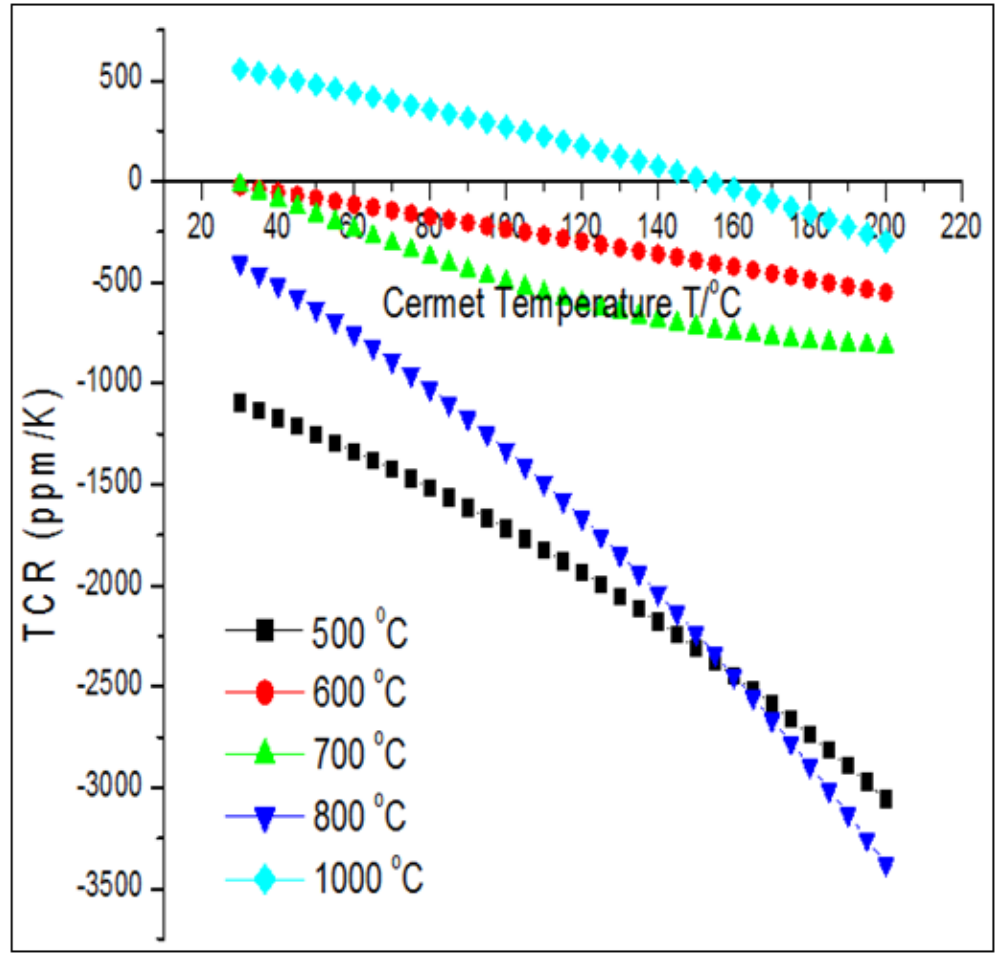

Figure 7. Variation of Temperature Coefficient of Resistance versus Cermet Temperature for $30 \%$ (vol.) Zn filler Content (Above the percolation threshold). 
Salman (2004) have pointed out that change in activation energies and TCR from positive to negative and vice versa could be an indication of the existence of phase transitions.

Above the percolation threshold for cermets annealed at temperatures between $500^{\circ} \mathrm{C}$ and $1000^{\circ} \mathrm{C}$, as seen in figure 7 , the TCR is small, predominantly negative and reduces slightly with increase in cermet temperature except for cermets annealed at $1000^{\circ} \mathrm{Cwhich}$ had an initial small positive TCR which also decreased with cermet temperature.

The exception may be due to a change of phase most likely due to chemical reaction of the cermets at the annealing temperatures greater than or equal to $1000^{\circ} \mathrm{C}$. Borek et al. (1998) have also obtained similar changes in TCR from positive to negative in $\mathrm{Cu}-\mathrm{Ni}$ and $\mathrm{Ni}-\mathrm{Cr}-\mathrm{Al}$ alloys. They attributed the changes to change in phase of the alloys from crystalline to amorphous as a result of temperature changes.

Based on several results obtained from the variation of Temperature Coefficient of Resistance with Cermet Temperatures about the percolation thresholds, we observed that measurement of TCR can be used to determine percolation threshold in cermets. We observe that above the percolation threshold, the rate of change of TCR with cermets temperature is negative at low cermet temperatures and reduces drastically by an order of at least 10 over the range of values obtained below the percolation thresholds.

\section{CONCLUSION}

In this article, we present some electrical properties of the zinc-kaolin cermet resistors with zinc metal fillers below the percolation threshold. Rectangular cermet rods of dimensions $65 \mathrm{~mm}$ by $6.5 \mathrm{~mm}$ by $3.2 \mathrm{~mm}$ were produced in a mould with semi-dry the zinc/kaolin powder mixture which is compressed with a force of about $1.32 \times 10^{5} \mathrm{~N}$. Sodium silicate solution (100 $\mathrm{g}$ of the solid $\mathrm{Na}_{2} \mathrm{SiO}_{4}$ was dissolved in $50 \mathrm{cl}$ of hot water) was used as a blinder for the cermets.

We observe that percolation threshold is both a function of the metal-kaolin ceramic mixture and the annealing temperature. The percolation threshold for cermets annealed at $300 \mathrm{and} 400^{\circ} \mathrm{C}$ is between 70 and $80 \%$ (vol.) while the cermets annealed at temperatures between 500 and $900^{\circ} \mathrm{C}$ is between 8 and 20\% (vol.). The unusually high percolation threshold for the cermet annealed at 300 and $400^{\circ} \mathrm{C}$ is attributed to the thin oxide coating on the $\mathrm{Zn}$ particles since zinc is readily oxidized. Hence conductivity is enhanced only when the density of zinc-zinc particle contact increase appreciably i.e. in the filler concentration of between $70-80 \%$ (vol.) $\mathrm{Zn}$. The low (C) CNCS, Mekelle University 
percolation threshold for the cermet annealed above $500^{\circ} \mathrm{C}$ is attributed the fibre nature of the zinc metal in the cermet structure. These fibres were produced as a result of flow of zinc metal through the microscopic pores of the cermet structures when the cermet structure is above the melting point of zinc.

The electrical conduction mechanism of the zinc-kaolin cermet below the percolation threshold is a mixture of both the hopping and the tunneling model with the hopping mechanism dominating. The temperature coefficient of resistance (TCR) is predominantly positive and large (30000-45000 $\mathrm{ppmK}^{-1}$ ) when cermet temperature is below $100^{0} \mathrm{C}$. The positive TCR is found to reduce with increasing cermet temperature until it becomes negative when cermet temperature exceeds $120^{\circ} \mathrm{C}$. The positive TCR observed is most likely the result of potential barriers created at grain boundaries i.e. double layers at grain boundaries may constitute Schottkey barriers, which are similar in respect to those formed in voltage dependent resistors.

It is observed that measurement of TCR can be used to determine percolation threshold in cermets. This is possible because above the percolation threshold, the change of TCR with cermets temperature is negative and has values which reduce drastically by at least an order of 10 over values obtained for cermets below the percolation thresholds.

\section{ACKNOWLEDGEMENTS}

Thank are due to Dr. Hagos and Dr. Bharadwaj for reviewing the paper and providing critical comments and suggestions which have improved the quality of the paper significantly.

\section{REFERENCE}

Abe, O \& Taketa, Y. 1991. Electrical Conduction in thick film resistors. J. Phys. D. Appl. Phys., 24: $1163-1171$.

Alcaniz-Monge, J.A., Cazorla-Amoros, D., Linares-Solano, A., Morallon, E \& Vazquez, J.L. 1998. Preparation of Conductive carbon-Ceramic Composite from Coal tar Pitch and Ceramic Monoliths. Carbon, 36(7-8):1003-1009.

Borek, J.J.V., Donkers, J.J.T.M., Rijt, R.A.F.V.D \& Janssen, J.T.M. 1998. Metal film precision resistors: resistive metal films and a new resistor concept. Philips J. Res., 51: 429-447. 
Gun, J., Tsionsky, M., Rabinovich, L., Golan, Y., Rubinstein, I \& Lev O. 1995. Electrochemical Characterisation and morphological Studies of palladium modified carbon Ceramics. $J$. Electroanal Chem., 39:57.

Hall, D. 1990. In: S.M. Lee (ed.), International encyclopaedia of composites, vol. 1, New York: $\mathrm{VCH}, 469 \mathrm{p}$.

Jacoboni, C., Prudenziati, M \& Rizzi, A. 1981. A simulative approach of electron conduction in thick film resistors. Proc. $3^{\text {rd }}$ Europ. Hybrid. Microel. conf. Avignom, pp.11-18.

Kanbara, T., Yamamoto, T., Ikawa, H., Tagawa, T \& Imai, H. 1987. Preparation and Characterization of porus and Electrically Conducting Carbon.Clay Composites. J. Mater Sci. Letters, 24:1552-1558.

Mantese, J.V \& Curtin, W.A. 1986. Two components model for the resistivity and noise of tunneling metal-insulator composites. Physical Review B. cond. Matter, 33: 7897-7902

Marko. 2000. Metal-Insulator transition in three-dimensional Anderson model: Scaling of Higher Lyaponor exponents, 33: L393-L398

Okutan, B., Bakan, H.I., Korkmaz, K \& Yakuphanoglu, F. 2005. Variable range hopping conduction and microstructural properties of semiconducting Co-doped $\mathrm{TiO}_{2}$. Physical B. 355: $176-181$

Pike, G.E \& Seager, C.H. 1977. Electrical properties and conduction mechanisms of Ru-based thick-film (cermet) resistors. J. Appl. Phys., 48(12): 5152-5168

Ponomarenko, A.T. Schevchenko, V.G \& Enikolopyan, N.S. 1990. Advances in polymer Science. Springer-Verlag. Berlin. Heidelberg.

Salman, F. 2004. AC conductivity and Dielectric study of chalcogenide glasses of Se-Te-Ge systems. Turk. J. Phys., 28: 41-48.

Sherman, R.D., Middleman, L.M \& Jacobs, S.M. 1983. Electron transport processes in conductor filled polymers. Polym. Eng. Sci., 23: 36.

Tsionsky, M., Gun, G., Glezer, V \& Lev, O. 1994. Sol-gel Derived Ceramic-Carbon Composite Electrodes: introduction and scope of applications. Anal Chem., 66(10):1747.

Vilcakova, J. 2000. Electric Percolation threshold of composite materials. Ph.D thesis, Brno University of Technology, Zlin, Czech Republic (unpubl.). 


\title{
Hybrid Solar - Wind - Diesel Systems for Rural Application in North Ethiopia: Case Study for Three Rural Villages using HOMER Simulation
}

\author{
Alfa Hailemariam Abraha ${ }^{1}$, Mulu Bayray Kahsay ${ }^{2 *}$ and Cuthbert Z.M. Kimambo ${ }^{3}$ \\ ${ }^{1}$ Mechanical Engineering, Energy and Environmental Management; University of Flensburg, \\ Germany (alpha_hailemariam@yahoo.com) \\ ${ }^{2}$ Department of Mechanical Engineering, Ethiopian Institute of Technology (EiT-M),Mekelle \\ University, Mekelle, Ethiopia (*mul_at@yahoo.com) \\ ${ }^{3}$ Mechanical and Industrial Engineering Department, University of Dar es Salaam, Tanzania \\ (kimambo@udsm.ac.tz)
}

\begin{abstract}
This paper considers the feasibility of developing Solar (photovoltaic)-Wind-Diesel hybrid power systems for supplying electricity to off-grid rural communities in the Tigray region of northern Ethiopia. Using wind resource assessment and solar potential-based data from the National Meteorological Agency of Ethiopia, a case study of three sites in Tigray is presented Serawet (645 households), Feleg Daero (338 households) and Adi Mesanu (55 households) which typify, respectively, large, medium and small off-grid communities. The energy demand was determined through a field survey and previous historical data of similar villages electrified through grid extension. The Hybrid Optimization Model for Electric Renewables (HOMER) was used to simulate and generate feasible solution through combinations of photovoltaic, Wind Turbines and Diesel Generators with a minimum levelised cost of electricity. The simulations indicate that a hybrid system option, compared to a diesel only system, is feasible for each of the three villages.
\end{abstract}

Keywords: Hybrid, HOMER, Photovoltaic, Wind energy, Solar energy, Rural electrification, Tigray, Ethiopia.

\section{INTRODUCTION}

In most developing countries electrifying rural households by extending the main grid is a major challenge due to economic and technical reasons. There is a need therefore to find other methods of supplying electricity to rural households. Supply of electricity to rural communities will have significant impact on preventing problems associated with deforestation, environmental effects and contributing towards sustainable development.

Like several other developing countries, Ethiopia is characterized by dependence on traditional biomass and most significantly, severe modern energy shortage in rural areas where more than $80 \%$ of the population of the country lives. Access to electricity is one of the lowest in Africa. Despite current efforts to increase access, many communities will not be reached for some years to come. On the other hand, Ethiopia is one of the countries endowed with renewable energy 
resources such as hydro, solar, wind and geothermal. Thus, renewable energy sources are options for off-grid electricity supply in the country. The northern part of the country where the study focuses on has high Solar and Wind energy potential. It is expected that hybrid Solar - Wind energy systems with diesel backup will provide good possibilities due to the complementary nature of the resources in the area.

This paper therefore demonstrates this fact by presenting a study made on hybrid Solar - Wind Diesel systems in three rural villages in the Tigray region of Northern Ethiopia, namely Serawat, Feleg Daero and Adi Mesanu; tries to demonstrate the feasibility of Solar-Wind-Diesel based hybrid systems for electrifying rural communities; and determine optimum configurations for the three sites.

\subsection{Literature Review}

\subsubsection{Solar Energy Resource Assessment}

Previous studies on solar energy resource assessment of the country include Neway (1996), Yacob and Frances (1996), Addis Ababa University (AAU) (2001), and Solar and Wind Energy Resource Assessment (SWERA) (2007). The study by Neway (1996) compared the measurement of global solar radiation with corresponding calculated values using Angestrom's relations. The regression coefficients were obtained and the correlation equations were determined to predict the global solar radiation. The results show that Angestrom's relations are valid for the locations under study. Yacob and Frances (1996) used sunshine hour records from 21 meteorological stations in the country to illustrate the general availability of the resource. The report by AAU indicated that the annual average daily solar radiation ranges from $4.25 \mathrm{kWh} / \mathrm{m}^{2}$ to $6.25 \mathrm{kWh} / \mathrm{m}^{2}$. Solar radiation maps of the country produced based on satellite data by SWERA (2007)also indicate that the country has significant solar radiation potential.

\subsubsection{Wind Energy Resource Assessment}

The first study reported on Wind energy potential of the country was by Welde Ghiorgis (1988). The study was based on wind speed data obtained from meteorological observations. The study shows estimates of the expected energy and explains reasons for expecting the calculated energy estimates to be potentially useful. Later studies include Yacob and Frances (1996) and SWERA (2007). Yacob and Fraces (1996) used wind and solar data from 21 meteorological stations and previous studies to illustrate the wind and solar energy potential across the country and SWERA 
(2007) came up with a map of wind and solar energy potential in the country.

\subsubsection{Hybrid Systems}

Studies made on hybrid system for Ethiopia are scarce. A study made by RENAC (2008) on feasibility of photovoltaic (PV)-diesel hybrid system for Ethiopia favored the PV-diesel hybrid system despite the high investment cost of the hybrid system. Another study made on the feasibility of solar - wind based hybrid system was reported by Bekele and Palm (2010). This study assessed the solar and wind energy potential for four locations in Ethiopia. HOMER software was employed to make the analysis for a model community of 200 households. However, the study concluded that the diesel power scheme (i.e. $100 \%$ diesel) was more feasible option than the solar-wind-diesel set up.

\section{DESCRIPTION OF THE STUDY SITES}

\subsection{Geographical Data of the Sites}

The current study has been conducted for three specific villages in North Ethiopia, in Enderta and Atsbi-Womberta Woredas of Tigray Region. The villages discussed here in this paper are: Serawat, Feleg Daero and Adi Mesanu. Other villages were part of the master's thesis study by Abraha (2011). Table 1 summarizes the geographical data of the villages. The three villages are models for large, medium and small size communities.

Table 1. Geographical data of the sites.

\begin{tabular}{|lllll|}
\hline Village Name & Longitude & Latitude & Altitude $(\boldsymbol{m})$ & No. of Households \\
\hline Serawat & $39.53 \mathrm{E}$ & $13.47 \mathrm{~N}$ & 2221 & 645 \\
\hline Feleg Daero & $39.47 \mathrm{E}$ & $13.52 \mathrm{~N}$ & 2001 & 338 \\
\hline Adi Mesanu & $39.74 \mathrm{E}$ & $13.88 \mathrm{~N}$ & 2511 & 55 \\
\hline
\end{tabular}

\subsection{Energy Demand Profile}

Energy demands of the population in the villages are for lighting, cooking, water pumping, milling cereals and refrigeration in health clinics. The load profile for the respective villages was determined by field survey and observing previous trends of similar villages recently electrified. The information for electrified villages and towns was obtained from the Ethiopian Electric Power Corporation (2010). The survey of the villages of the current study was conducted to determine the number of households, number of rooms per household and other energy demand 
in the villages. The survey determined the lighting load, cooking load, energy needed to replace diesel operated water pumps, milling stations and energy demand of health clinics. Figure 1 shows the load profile of the villages. The peak load is from 18.00-24.00 hours due to the expected significant lighting load in the households.

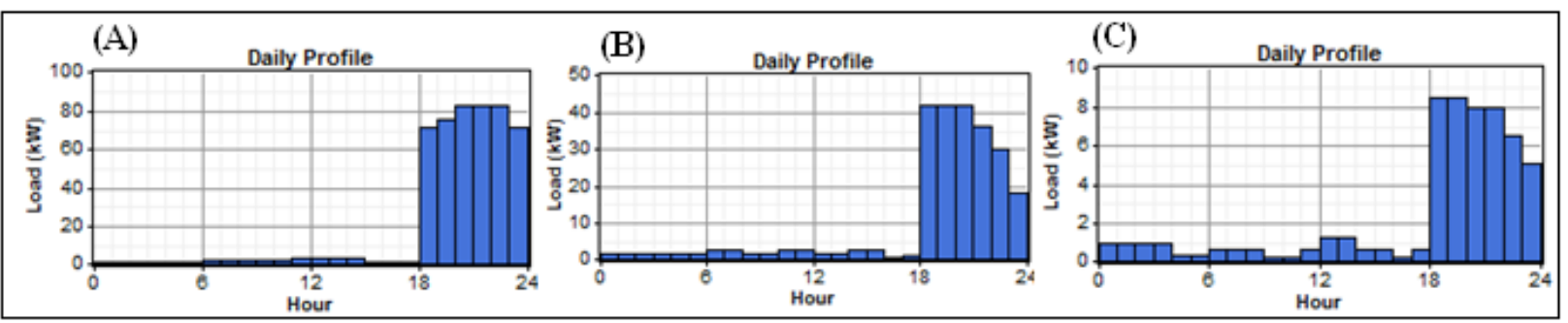

Figure 1. Load Profile for Serawat (A), Feleg Daero (B), Adi Mesanu (C).

Table 2. Summary of the load profiles for the sites

\begin{tabular}{|lllll|}
\hline Village Name & $\begin{array}{l}\text { Average Daily } \\
\text { Demand }(\boldsymbol{k W h})\end{array}$ & $\begin{array}{l}\text { Average Power } \\
(\boldsymbol{k W})\end{array}$ & $\begin{array}{l}\text { Peak Power } \\
(\boldsymbol{k W})\end{array}$ & Load Factor \\
\hline Serawat & 497 & 20.7 & 146 & 0.14 \\
\hline Feleg Daero & 238 & 9.9 & 74 & 0.13 \\
\hline Adi Mesanu & 55 & 2.3 & 14.9 & 0.15 \\
\hline
\end{tabular}

To account for the day to day and hour to hour variability, $15 \%$ and $20 \%$ variability respectively, was introduced to the average daily load profiles shown in figure 1 which resulted in higher peak power demand. A summary of the load profiles after the variability has been applied to the average load for all the three villages is shown in table 2 . The power demand has a low load factor as shown in table 2 and is characterized by low energy demand during the day time and peak demand during the evening. This is because of the fact that electricity is primarily used for lighting application and the lack of commercial and industrial demand in the villages.

\subsection{Solar Energy Resource}

The most common solar energy resource data collected in many of the meteorological stations throughout the country is the average daily sunshine hours. The available sunshine hour data from the National Meteorological Agency of Ethiopia (2010) was used to estimate the solar energy resource of the sites. Figure 2 shows the eight years average daily sunshine hours in each month for the sites under study. 


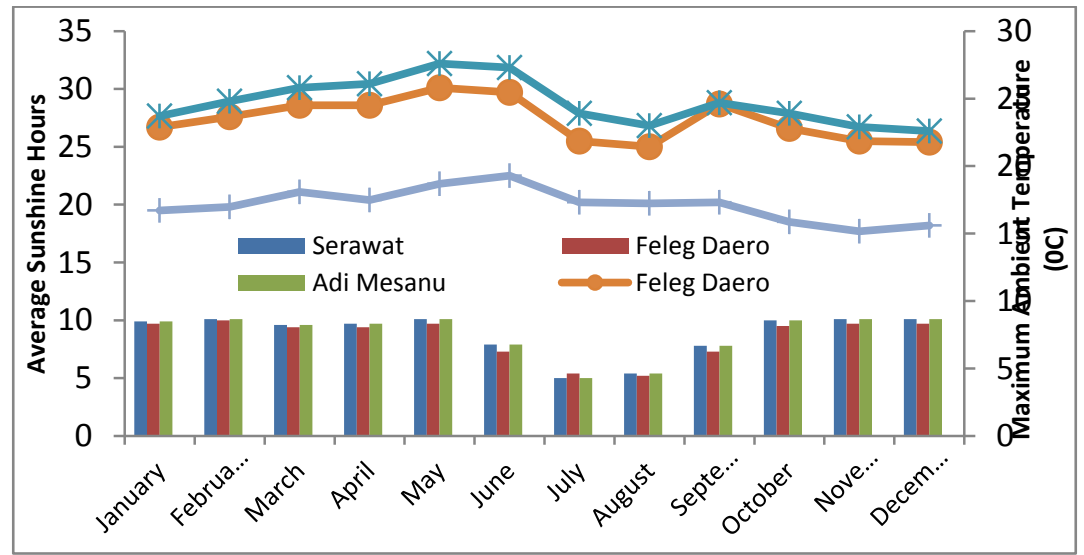

Figure 2. Average Sunshine Hours and Maximum Temperature.

\subsection{Wind Energy Resource}

Wind energy data are measured at $2 \mathrm{~m}$ above ground in many meteorological stations in Ethiopia though wind speed measurements at $10 \mathrm{~m}$ are available at some airports and are more useful for predicting Wind Turbine power. Even though recently wind energy resource assessment for power generation has been conducted at some sites, the available data for these sites during the period of this study was $2 \mathrm{~m}$ data from the National Meteorological Agency (2010). Thus eight year monthly average wind speed data measured at $2 \mathrm{~m}$ was used for the resource assessment, with subsequent extrapolation to $10 \mathrm{~m}$ values. Data under collection at Ethiopian Institute of Technology-Mekelle University (EiT-M) at 10m was considered for comparison purposes (Mulu, 2011).

\section{METHODOLOGY}

\subsection{Modeling Daily Solar Radiation}

The sunshine hour data available has been converted to monthly average daily global solar radiation, $H_{G}$, from $\mathrm{H}_{0}$, the monthly average daily extraterrestrial radiation, employing theAngestrom - Page estimation model(Duffie and Beckman, 1980), given by Equation 1.

$H_{G}=H_{o}\left(a+b \frac{n}{N}\right)$

Where

$\mathrm{H}_{\mathrm{G}}$ ismonthly average daily global solar radiation

$\mathrm{H}_{\mathrm{O}}$ is monthly average daily extraterrestrial solar radiation

a is Angestrom's correlation parameter

(c) CNCS, Mekelle University 
b is Angestrom's correlation parameter

$\mathrm{n}$ is monthly average daily hours of sunshine from sunshine recorder

$\mathrm{N}$ is monthly average of the maximum possible hours of sunshine

$\mathrm{H}_{\mathrm{o}}$ is determined based on the Solar Constant, average day of the month and the declination angle. The values for $\mathrm{N}$, $\mathrm{a}$ and $\mathrm{b}$ were determined using Equations 2, 3 and 4.

$\mathrm{N}=\frac{2}{15} \cos ^{-1}(-\tan \Phi \tan \delta)$

$a=-0.309+0.539 \cos \Phi-0.0693 E o+0.290\left(\frac{n}{N}\right)$.

$b=1.527-1.027 \cos \Phi+0.0926 E o-0.359\left(\frac{n}{N}\right)$

Where

Eo is Altitude of a site in kilometers

$\delta$ is declination angle for the average day in the month

$\alpha$ is Hellman coefficient

$\Phi$ is Latitude of the site

\subsection{Wind Speed Profile}

The wind speed data available as discussed in section 3 is measurement data at $2 \mathrm{~m}$. Such a measurement has its own limitation since it is prone to shading by buildings and vegetation. However, it can be used in the absence of other data by making use of wind shear effects. The plot of the $2 \mathrm{~m}$ monthly average data is shown in figure 3 .

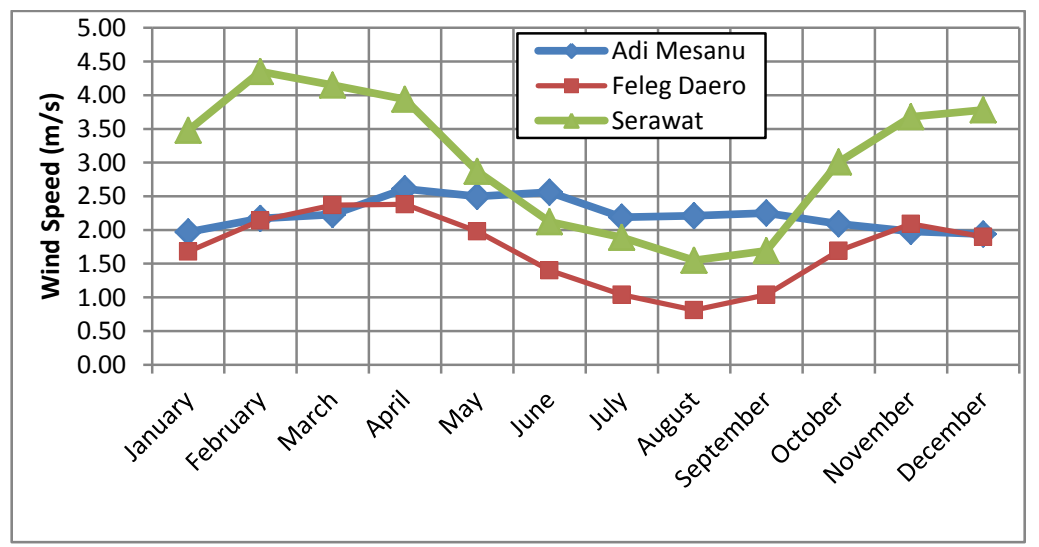

Figure 3. Wind Speed at $2 \mathrm{~m}$ height from Meteorological Stations.

The Hellman exponential law also known as the Power law is used here to find the wind speed at turbine hub height from the data at $2 \mathrm{~m}$ as given in Equation 5 . 


$$
\frac{\mathrm{V}_{\mathrm{Z}}}{\mathrm{V}_{\mathrm{Z} \text { ref }}}=\left[\frac{\mathrm{z}}{\mathrm{z}_{\mathrm{ref}}}\right]^{\alpha}
$$

The Hellman coefficient $\alpha$ can be computed by the empirical formula given in Equation 6

$\alpha=0.096 \log _{10} \mathrm{Z}_{\mathrm{o}}+0.016\left(\log _{10} \mathrm{Z}_{\mathrm{o}}\right)^{2}+0.24$

Where

$\mathrm{V}_{\mathrm{Z}}$ is mean wind speed at height $\mathrm{Z}$

$V_{\text {zref }}$ is mean wind speed at the reference height of the study terrain

$\mathrm{Z} \quad$ is study height above the ground

$\mathrm{Z}_{\mathrm{ref}}$ is reference height, $2 \mathrm{~m}$

$\mathrm{Z}_{0} \quad$ is surface roughness length

Zo value ranges $0.001 \mathrm{~m}<\mathrm{Zo}<10 \mathrm{~m}$ and the surface roughness for the sites was considered in the range of few trees $(\mathrm{Zo}=0.1)$ to many trees and few buildings $(\mathrm{Zo}=0.25)$. Therefore, the average Helleman coefficient of $\alpha=0.2$ was used in the calculations.

\subsection{Hybrid Modeling in HOMER}

HOMER software has been used for the modeling, analysis and optimization. The software takes solar energy and wind energy data; models PV, wind turbine, diesel generator and batteries with different sizes to match the demand; makes economic analysis considering costs of components. Optimization is based on Levelized Cost of Electricity (LCOE) which is defined as the ratio of the sum of the levelized annual cost to the annual electricity production of the system. The system with the least LCOE meeting the power demand of the village is considered to be the optimized option.

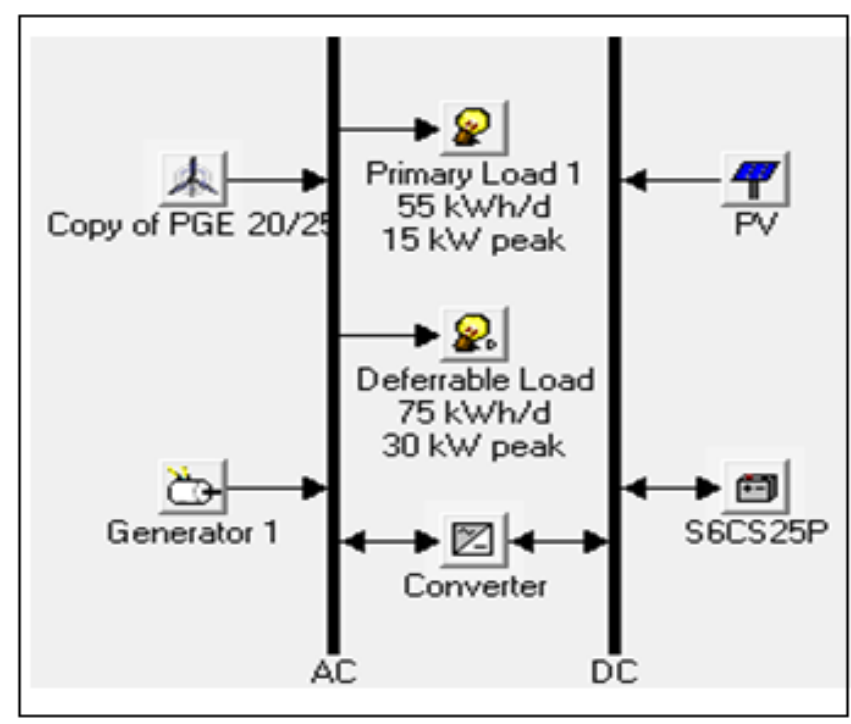

Figure 4. A HOMER Model Representation of a Parallel Hybrid System. 
The hybrid system modeled in this study for each village consists of PV, wind turbine, diesel generator as power sources. The system also includes battery storage and inverter. The type of the hybrid system modeled is a parallel hybrid system. The parallel system has an alternating current (AC) and direct current (DC) buses as shown in figure 4. The wind turbine and the generator with $\mathrm{AC}$ power sources are connected to the AC bus. The PV and battery are connected to the DC bus. The parallel system was selected compared with series or switched system for its advantage of higher overall efficiency and avoiding double conversion of electricity from AC to DC and vice versa.

Among the physical properties of the diesel generator which are required as input to HOMER include power output capacity, expected life time in operating hours and fuel consumption. In addition, economic parameters such as capital cost, replacement cost, operation and maintenance cost are required. A synchronous type alternator directly coupled to the diesel engine is selected. The efficiency of the generator is assumed to be $35-45 \%$. Since the fuel consumption depends on the operating power, fuel consumption at part load was included in the modeling to account for the decreased efficiency when the generator is not working at full load. To avoid very low efficiency operation the minimum load ratio for the generator is taken to be $40 \%$.Capital costs of $\$ 32,500, \$ 28,829$ and $\$ 23,283$ were used for high speed generators of $180 \mathrm{~kW}, 100 \mathrm{~kW}$ and $45 \mathrm{~kW}$ capacity for Serawat, Feleg Daero and Adi Mesanu respectively. Life time of 15,000 running hours has been considered. The combined operating and maintenance cost of the diesel generators, which takes in to account the operating costs, maintenance costs and future price uncertainties, is $\$ 65 / \mathrm{hr}$, $\$ 37.5 / \mathrm{hr}$ and $\$ 18.1 / \mathrm{hr}$ for Serawat, Feleg Daero and Adi Mesanu respectively.

Due to its low cut-in wind speed, ease of transportation and erection, appropriate rated capacity and cost, the PGE25 wind turbine with a rated capacity of $25 \mathrm{~kW}$ AC and manufactured by PGE Energy of Canada has been selected for the analysis. The capital cost of the wind turbine including electrical components, foundation, erection and other site activities is $\$ 42,250$ with an annual operation and maintenance cost of $\$ 2,499$. The technical specifications of the wind turbine are given in table 3.

Typical specifications were also taken for the PV modules. The efficiency of the PV modules was assumed to be $13 \%$ with nominal operating temperature of $47^{0} \mathrm{C}$. The temperature 
coefficient of power was considered to be $-0.5 \% /{ }^{0} \mathrm{C}$ and a life of 25 years. The capital cost for small scale PV systems is higher than for large scale applications and the costs related to distribution and transportation are expected to have an impact in this case. Thus a capital cost of $\$ 4000 / \mathrm{kW}$ and an annual operation and maintenance cost of $\$ 20 / \mathrm{kW}$ has been considered.

Table 3. Technical specifications of the PGE25 wind turbine.

\begin{tabular}{|ll|}
\hline Parameter & Values \\
\hline Rated Power & $25 \mathrm{~kW} \mathrm{AC}$ \\
\hline Available Tower Heights & $20 / 30 / 36$ meters \\
\hline Selected Tower Height & 36 meters \\
\hline Rotor Diameter & 20 meters \\
\hline Swept Area & $305 \mathrm{~m}^{2}$ \\
\hline Rotational Speed & $32 \mathrm{rpm}$ \\
\hline Cut in Wind Speed & $3.5 \mathrm{~m} / \mathrm{s}$ \\
\hline High Wind Speed Cut out & $25 \mathrm{~m} / \mathrm{s}$ \\
\hline Low Wind Speed Cut out & $1.7 \mathrm{~m} / \mathrm{s}$ \\
\hline
\end{tabular}

To optimize the system for better performances, create a buffer for engine start ups, provide system stability and store excess electricity generated from PV panels for later uses; batteries have also been considered as part of the modeled system. A Surette 6CS25P battery with a nominal capacity of $1156 \mathrm{Ah}$ and Nominal voltage of $6 \mathrm{~V}$ was used as an input for the simulation. To avoid losses and reduce conductor sizes a system bus voltage of $48 \mathrm{~V}$ has been chosen. Thus, there are 8 batteries per string (8x6) which result in $48 \mathrm{~V}$. A capital cost of $\$ 833$ and annual operation and maintenance cost of $\$ 15$ have been used as economic parameters for the battery.

An AC/DC bidirectional converter is also required to convert the DC electricity from the PV panels and the batteries to feed the AC loads as well as charge the batteries from the excess AC electricity produced by the diesel generator and wind-turbine. The AC/DC inverter used in the modeling has an efficiency of $85 \%$ in the rectifier mode and $90 \%$ in the inverter mode. Life time of 10 years and a capital cost of $\$ 700$ have been used.

The last sets of economic inputs parameters used are the interest rate, diesel fuel price and the prevailing exchange rates from Ethiopian Birr (ETB) to USD used at the time of the study. A 9\% interest rate, 16.37 ETB/ 1 \$ exchange rate and diesel fuel price of \$0.98/liter was used according to data obtained from the National Bank of Ethiopia and the Ministry of Trade. 


\section{RESULTS AND DISCUSSION}

This section shows the results of the solar and wind resource analysis, the optimization and simulation of the system on HOMER and presents the discussion of the outputs of the optimization model.

\subsection{Results from the Estimation Model of Solar Radiation}

The Angstrom estimation model discussed in section 4 was used to find the monthly average daily global solar radiation by using input data such as latitude, altitude, the average day in the month, the declination angle for the day and the sunshine hour data. A worksheet was created with all the input data for each month and employing Equations $1-4$ the parameters $\mathrm{N}, \mathrm{a}, \mathrm{b}, \mathrm{H}_{0}$ and finally $\mathrm{H}_{\mathrm{G}}$ were calculated. The worksheet for Serawat is shown in Annexure 1 as a sample. Monthly clearness index defined as the ratio of solar radiation received on the earth's surface to the extraterrestrial radiation $\left(\mathrm{H}_{\mathrm{G}} / \mathrm{H}_{\mathrm{o}}\right)$ has been calculated for each site as well. The results of the estimation model indicate very close values for the solar radiation in the three sites. This is due to the fact that the sites are located close to each other and there is only a slight variation in the altitude of the sites. The average daily global solar radiation varies from around 5.0 $\left(\mathrm{kWh} / \mathrm{m}^{2} /\right.$ day $)$ in rainy month of July to just above $7.0\left(\mathrm{kWh} / \mathrm{m}^{2} /\right.$ day $)$ in the dry months. Similarly the clearness index varies from the lowest value of 0.5 in July to the highest value of 0.67 in most of the months of the year. Thus, according to Kudish and Ianetz (1996), the three sites can be classified as clear sky for most times of the year and partially cloudy during the rainy season.

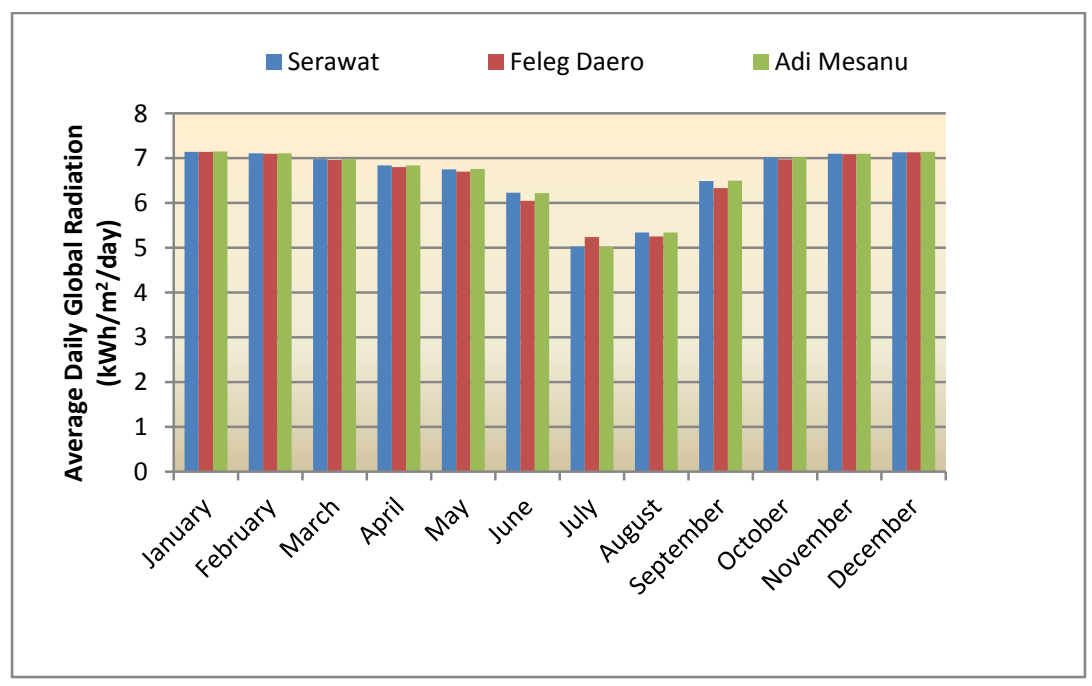

Figure 5. Calculated Global Solar Radiation for each month. 
The final calculated results of the monthly average daily global solar radiation $\mathrm{H}_{\mathrm{G}}$ is shown in figure 5. The monthly average daily global solar radiation $\mathrm{H}_{\mathrm{G}}$ has been used as an input for the HOMER analysis.

\subsection{Results from the Wind Resource Data Analysis}

The wind speed data at $2 \mathrm{~m}$ height from the National Meteorology Agency is shown in table 4 . The data at $2 \mathrm{~m}$ height was extrapolated to wind speed data at 10 mbased on the Hellman exponential law presented in Equation 5. The extrapolation result at $10 \mathrm{~m}$ is shown in figure 6. The site at Serawat has relatively higher wind speed with a significant seasonal variation. The wind speed varies from around $2 \mathrm{~m} / \mathrm{s}$ in August to around $6 \mathrm{~m} / \mathrm{s}$ in February. Adi Mesanu has low wind speed resource with wind speeds of around $3 \mathrm{~m} / \mathrm{s}$ showing no significant seasonal variation. Among the three sites Feleg Daero showed low wind speed varying from $1 \mathrm{~m} / \mathrm{s}$ in August to slightly above $3 \mathrm{~m} / \mathrm{s}$ in March again with significant seasonal variations. The wind speed data at $2 \mathrm{~m}$ and wind shear coefficient of 0.2 were used as input data for the HOMER analysis. HOMER extrapolates the $2 \mathrm{~m}$ data to the hub height of the turbine considered which is $36 \mathrm{~m}$.

Table 4. Average Wind speed in $\mathrm{m} / \mathrm{s}$ at $2 \mathrm{~m}$ height from NMA.

\begin{tabular}{|llllllllllll|}
\hline $\begin{array}{l}\text { Village } \\
\text { Name }\end{array}$ & January & February & March & April & May & June & July & August & September October December \\
\hline Serawat & 3.48 & 4.35 & 4.15 & 3.94 & 2.87 & 2.12 & 1.89 & 1.55 & 1.69 & 3.01 & 3.78 \\
\hline $\begin{array}{l}\text { Feleg } \\
\text { Daero }\end{array}$ & 1.68 & 2.14 & 2.37 & 2.38 & 1.98 & 1.4 & 1.04 & 0.81 & 1.04 & 2.09 & 1.9 \\
\hline $\begin{array}{l}\text { Adi } \\
\text { Mesanu }\end{array}$ & 1.97 & 2.17 & 2.23 & 2.61 & 2.5 & 2.56 & 2.19 & 2.21 & 2.25 & 1.98 & 1.94 \\
\hline
\end{tabular}

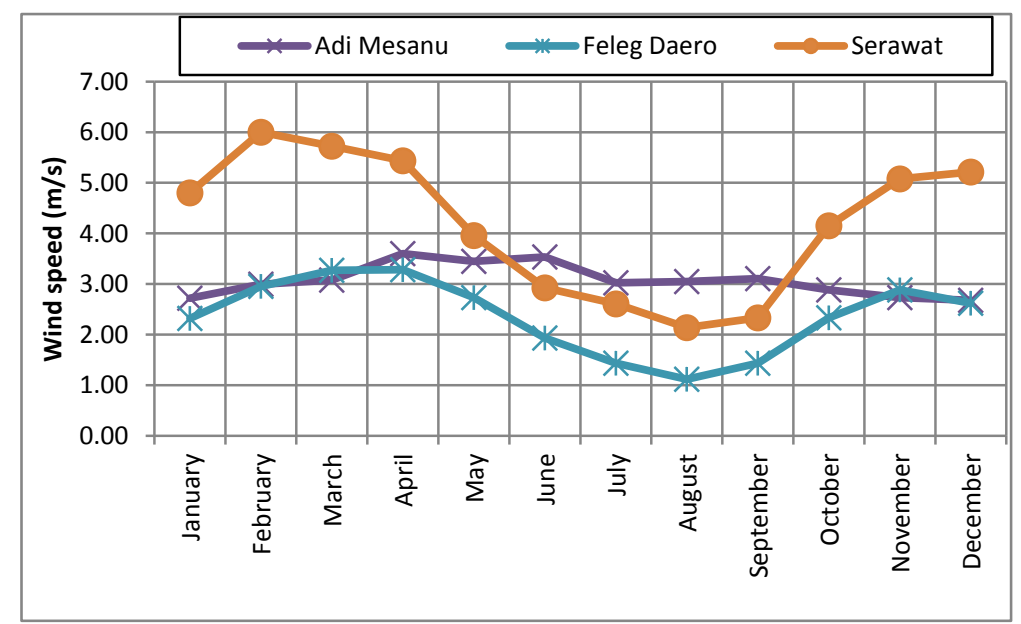

Figure 6. Extrapolated Wind Speed Data at $10 \mathrm{~m}$. 
To check the accuracy of the extrapolation, the result of the data for Serawat was compared with data being measured at EiT-M (Mulu, 2011) to determine the correlation between those two data sets. Even though slight differences in the absolute value of the results exist, a correlation analysis resulted in a correlation coefficient of 0.92 which indicated that there is a strong relationship between the two data sets. The monthly averages of the wind data measurement at EiT-M and the extrapolated data for Serawat are show in figure 7.

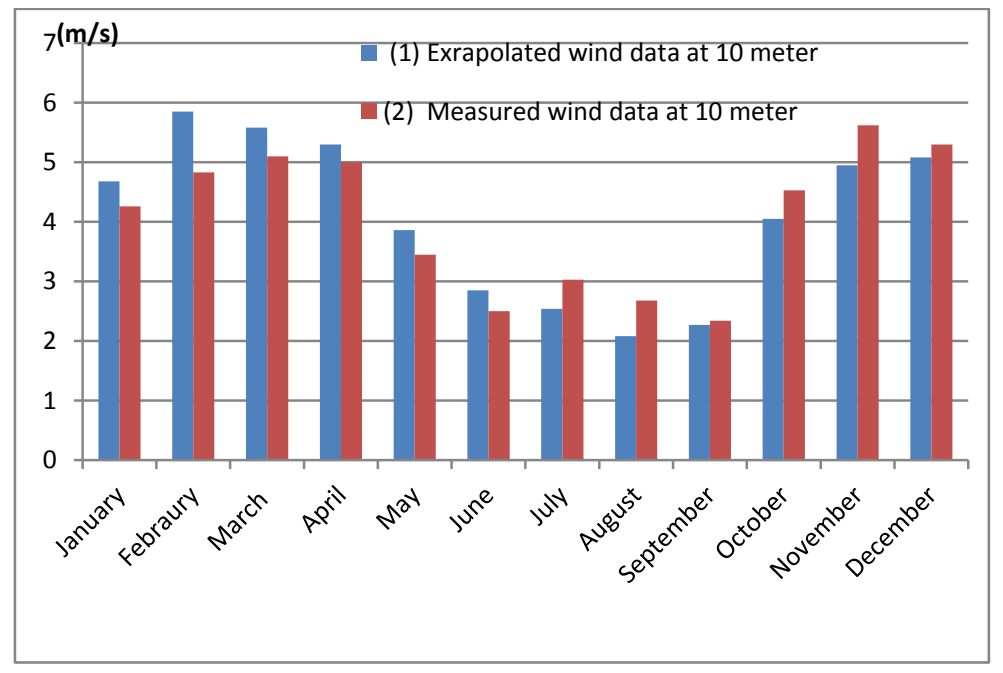

Figure 7. Measured and Extrapolated Monthly Average Wind Speeds, Serawat.

As can be seen from figure 7 the extrapolated data resulted in slightly higher values than the measured wind speed data for the months January to June where as in the months July to December the extrapolated average wind speeds are slightly lower than the measured values.

\subsection{Results from the Hybrid System Analysis and Optimization using HOMER}

HOMER software models were created for conducting the analysis. Based on the load profile discussed in section 3 appropriate sizes and numbers of equipments to be considered were selected for each site. The necessary energy resource inputs from solar and wind were supplied fromthe results discussed in previous sub-sections 4.1 and 4.2. The equipment representation of the hybrid systems for Serawat, Feleg Daero and Adi Mesanu are shown in figure 8(A), (B) and (C) respectively. The equipment configuration of the three sites is similar, the only difference being on the capacity of the primary and deferrable loads.

The results of the optimization in HOMER for the sites are discussed in the subsequent sections. In each case a table showing a listing of selected feasible system options is given (Tables 5-7). 
Amongst the options, the table shows system architectures for the least cost system, 100\% renewable penetration system and $100 \%$ diesel option. Similarly, for each case a figure showing electricity production contribution of each technology on a monthly basis is given (Figures 9-10).
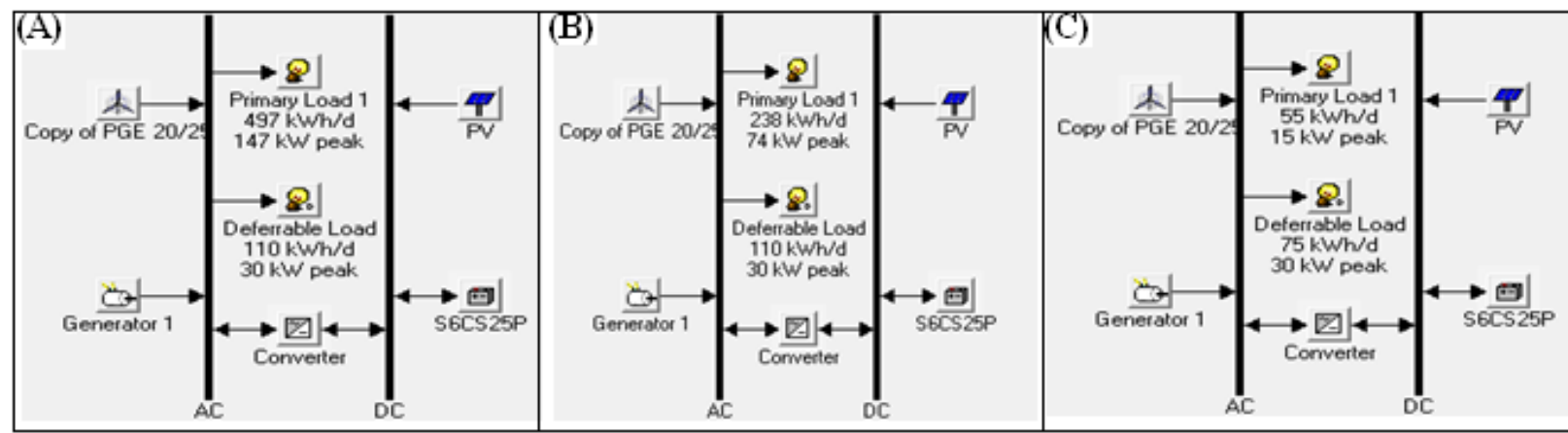

Figure 8. Equipment Representations of the Hybrid Systems, (A) Serawat, (B) Feleg Daero, and (C) Adi Mesanu.

\subsubsection{Serawat}

A summary of the optimization results in a categorized form for Serawat has been presented in table 5. The least cost option for this site is the wind-diesel option. This is primarily because of the good wind resource of the site and the cheaper price per installed capacity of the wind turbine as compared to PV. Figure 9 shows the share of average monthly electricity production by the wind turbine and the diesel generator. As can be seen from the figure 9 the diesel generator is used as back up in most of the months in the year, supplying less than $10 \%$ of total energy generated except in the months June to September, where a larger proportion of the produced energy comes from the diesel generator.

Table 5. Categorized optimization results for Serawat according to net present cost.

\begin{tabular}{|c|c|c|c|c|c|c|c|c|c|}
\hline $\begin{array}{l}P V \\
(k W)\end{array}$ & $\begin{array}{l}\text { Number } \\
\text { of Wind } \\
\text { Turbines }\end{array}$ & $\begin{array}{l}\text { Diesel } \\
\text { Generator } \\
(k W)\end{array}$ & $\begin{array}{l}\text { No. of } \\
\text { Batteries }\end{array}$ & $\begin{array}{l}\text { Converter } \\
(k W)\end{array}$ & $\begin{array}{l}\text { Total Capital } \\
\text { Cost }(\$)\end{array}$ & $\begin{array}{l}\text { Total Net } \\
\text { Present } \\
\text { Cost }(\$)\end{array}$ & $\begin{array}{l}\text { LCOE } \\
(\$ / k W h)\end{array}$ & $\begin{array}{l}\text { Renewable } \\
\text { Fraction }\end{array}$ & $\begin{array}{l}\text { Diesel } \\
\text { Consum- } \\
\text { ption } \\
(\text { L/Year })\end{array}$ \\
\hline 0 & 5 & 110 & 240 & 100 & 501,031 & $1,248,119$ & 0.574 & 0.86 & 17,507 \\
\hline 5 & 5 & 110 & 240 & 100 & 521,031 & $1,253,599$ & 0.576 & 0.87 & 16,898 \\
\hline 180 & 0 & 70 & 400 & 150 & $1,170,839$ & $1,526,634$ & 0.702 & 0.94 & 5,767 \\
\hline 180 & 3 & 0 & 560 & 130 & $1,404,230$ & $1,733,954$ & 0.797 & 1.00 & 0 \\
\hline 0 & 0 & 150 & 0 & 0 & 27,083 & $6,161,842$ & 2.831 & 0 & 137,797 \\
\hline
\end{tabular}






Figure 9. Power Shares of Components for the Optimal Wind-Diesel System at Serawat.

The least cost wind-diesel hybrid option for this site has 5 Wind Turbines and a $110 \mathrm{~kW}$ diesel generator, with a Levelized Cost of Electricity (LCOE) of $0.574 \$ / \mathrm{kWh}$. To attain a $100 \%$ renewable option, $180 \mathrm{~kW} \mathrm{PV,} 3$ wind turbines and a battery bank should be combined which raises the LCOE to $0.702 \$ / \mathrm{kWh}$. The last row of table 5 shows the $100 \%$ diesel option which will have a significantly higher LCOE of $2.83 \$ / \mathrm{kWh}$.

\subsubsection{Feleg Daero}

Similarly, the optimization results for Feleg Daero site are shown in table 6. The least cost option for this site is the PV-wind-diesel option. As in the previous case the diesel generator is used as back up except for the months June to September where PV and wind could not supply the required energy.

Table 6. Categorized optimization results for feleg Daero according to net present cost.

\begin{tabular}{|c|c|c|c|c|c|c|c|c|c|}
\hline $\begin{array}{l}P V \\
(k W)\end{array}$ & $\begin{array}{l}\text { Number of } \\
\text { Wind } \\
\text { Turbines }\end{array}$ & $\begin{array}{l}\text { Diesel } \\
\text { Generator } \\
(k W)\end{array}$ & $\begin{array}{l}\text { Number } \\
\text { of } \\
\text { Batteries }\end{array}$ & $\begin{array}{l}\text { Converter } \\
(\mathrm{kW})\end{array}$ & $\begin{array}{l}\text { Total Capital } \\
\text { Cost }(\$)\end{array}$ & $\begin{array}{l}\text { Total Net } \\
\text { Present } \\
\text { Cost }(\$)\end{array}$ & $\begin{array}{l}L C O E \\
(\$ / k W h)\end{array}$ & $\begin{array}{l}\text { Renewable } \\
\text { Fraction }\end{array}$ & $\begin{array}{l}\text { Diesel } \\
\text { Consum- } \\
\text { ption } \\
\text { (L/Year) }\end{array}$ \\
\hline 30 & 2 & 50 & 120 & 50 & 353,875 & 754,408 & 0.605 & 0.85 & 11,299 \\
\hline 0 & 3 & 50 & 160 & 70 & 323,445 & 766,324 & 0.614 & 0.85 & 13,092 \\
\hline 100 & 0 & 30 & 200 & 70 & 624,249 & 886,466 & 0.711 & 0.91 & 5,991 \\
\hline 100 & 2 & 0 & 320 & 90 & 814,060 & $1,030,860$ & 0.827 & 1.00 & 0 \\
\hline 0 & 0 & 85 & 0 & 0 & 24,505 & $3,758,776$ & 3.012 & 0 & 89,144 \\
\hline
\end{tabular}






Figure 10. Power Shares of Components for the Optimal PV-Wind-Diesel System, Feleg Daero.

Figure 10 shows the average monthly electricity production of each component. The LCOE for this system is $0.605 \$ / \mathrm{kWh}$, with $30 \mathrm{~kW} \mathrm{PV}$, two Wind-Turbines and $50 \mathrm{~kW}$ Diesel Generator. In the $100 \%$ renewable penetration option, the LCOE increases to $0.827 \$ / \mathrm{kWh}$. In the case of a $100 \%$ diesel supply indicated in the last row of Table 6 the LCOE surges to $3.012 \mathrm{USD} / \mathrm{kWh}$.

\subsubsection{Adi Mesanu}

The results for Adi Mesanu also show similar results to that of Serawat and Feleg Daero. The optimization results for Adi Mesanu site have been summarized in table 7. The least cost option for this site is PV-Wind-Diesel option with more wind penetration. Figure 11 shows the contribution of each technology towards the monthly electricity production and it can be observed that the diesel generator is used as a backup for most of the months throughout the year, though it makes its biggest contributions in January and December.

Table 7. Categorized optimization results for Adi mesanu according to net present cost.

\begin{tabular}{|c|c|c|c|c|c|c|c|c|c|}
\hline \begin{tabular}{|l|}
$P V$ \\
$(k W)$
\end{tabular} & $\begin{array}{l}\text { Number o } \\
\text { Wind } \\
\text { Turbines }\end{array}$ & $\begin{array}{l}\text { fDiesel } \\
\text { Generator } \\
(k W)\end{array}$ & $\begin{array}{l}\text { Number } \\
\text { of } \\
\text { Batteries }\end{array}$ & $\begin{array}{l}\text { Converter } \\
(\mathrm{kW})\end{array}$ & $\begin{array}{l}\text { Total } \\
\text { Capital } \\
\text { Cost (\$) }\end{array}$ & $\begin{array}{l}\text { Total N } \\
\text { Present } \\
\text { Cost }(\$)\end{array}$ & $\begin{array}{l}\text { et LCOE } \\
\quad(\$ / k W h)\end{array}$ & $\begin{array}{l}\text { Renewable } \\
\text { Fraction }\end{array}$ & $\begin{array}{l}\text { Diesel } \\
\text { Consum- } \\
\text { ption } \\
(\text { L/Year }) \\
\end{array}$ \\
\hline 5 & 1 & 10 & 32 & 10 & 101,081 & 191,580 & 0.410 & 0.90 & 2,184 \\
\hline 0 & 1 & 10 & 32 & 10 & 81,081 & 198,261 & 0.425 & 0.84 & 3,377 \\
\hline 15 & 1 & 0 & 80 & 15 & 179,390 & 241,049 & 0.517 & 1.00 & 0 \\
\hline 0 & 0 & 15 & 0 & 0 & 7,762 & 781,317 & 1.673 & 0 & 22,009 \\
\hline
\end{tabular}

(C) CNCS, Mekelle University $76 \quad$ ISSN:2220-184X 


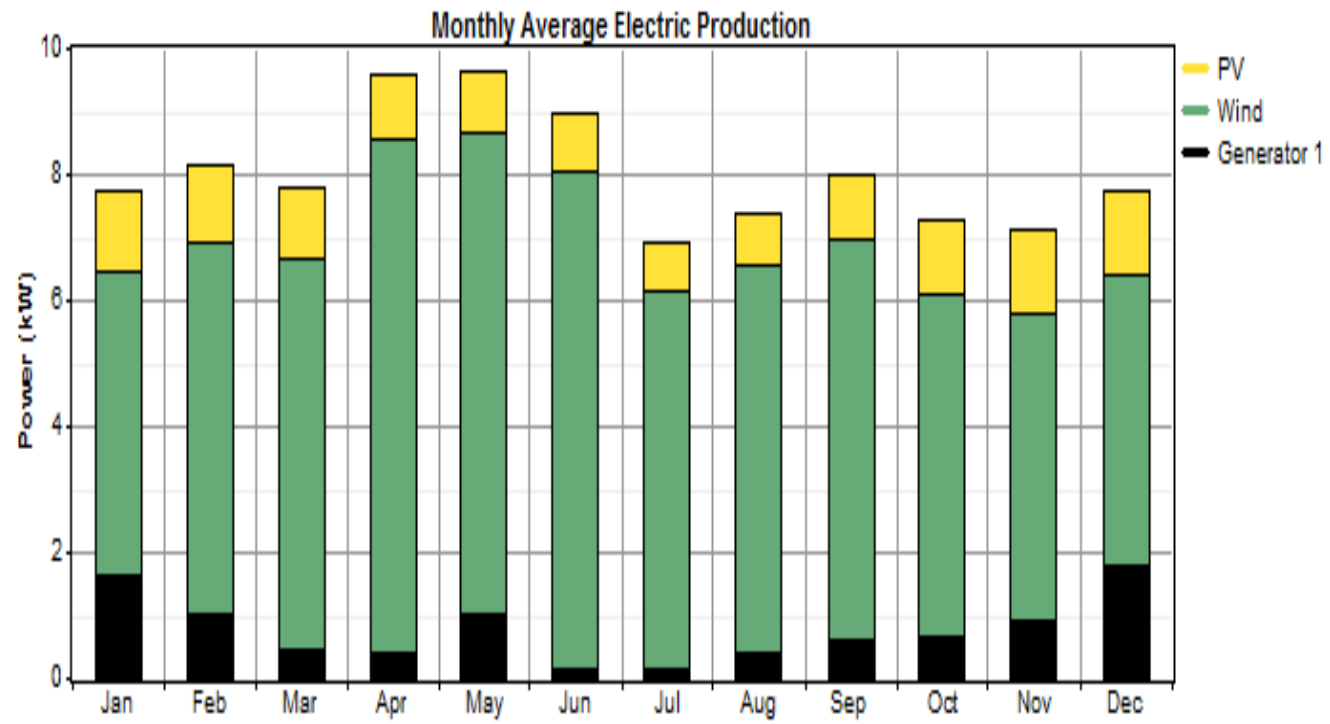

Figure 11. Power Shares of Components for the Optimal PV-Wind-Diesel System, Adi Mesanu.

Due to increased penetration of wind and PV production as compared to the optimal systems from the other sites resulting in reduced running hours of the diesel generator the LCOE of this hybrid system is the lowest of the three sites at $0.410 \$ / \mathrm{kWh}$. The LCOE for the $100 \%$ renewable option and $100 \%$ diesel option are $0.517 \$ / \mathrm{kWh}$ and $1.673 \$ / \mathrm{kWh}$ respectively.

\section{CONCLUSION}

Like many other parts of the country the Northern part of Ethiopia is characterized by low electrification rate in rural areas, dependence on fuel wood and dung for cooking. Kerosene is widely used in wick lamps and hurricane lamps in areas where there is no access to electricity. Despite the extensive rural electrification scheme being carried out, due to the dispersed nature of the rural settlements and low energy demands it will be difficult to reach out to every corner through grid extension.

This paper has thus presented an option of rural electricity supply through Solar-Wind-Diesel hybrid systems. It has been shown that the three sites taken as a case study have limited wind resource. Even though the sites have an excellent solar resource the optimal system configurations obtained through simulation in HOMER have higher wind penetration than PV due to higher capital costs for PV. Due to the continued reduction in PV module prices, PV could also be a major component in the hybrid systems in the area. Though the levelized cost of (C) CNCS, Mekelle University 
electricity from the hybrid systems demonstrated in this study is highly comparable to the subsidized electricity price in the country; it is significantly lower than a diesel only electricity supply. This will bring major advantages by alleviating incidents related to indoor pollution, encouraging small scale productive activities and reducing burden on the country's economy by replacing imported fuel.

\section{ACKNOWLEDGMENTS}

The authors would like to thank the National Meteorological Agency of Ethiopia (NMA) and the Ethiopian Electric Power Corporation (EEPCo) for providing data used in the study. The authors would also like to thank NOMA for providing financial support. The comments and suggestions provided by the reviewers Dr. Dilip, Dr. Venkatesan and Dr. John Paintin are highly appreciated and duly acknowledged.

\section{REFERENCE}

Abraha, A. H., 2011. Hybrid Solar-Wind-Diesel Systems for Rural Application in North Ethiopia. M.Sc thesis, University of Dar es Salaam, Tanzania.

Addis Ababa University (AAU), 2001. Renewable Energy Resource and Technologies. Final Report, V. II, Electrical and Computer Engineering Department, Addis Ababa University, Addis Ababa, Ethiopia.

Bekele, G \& Palm, B., 2010. Feasibility Study for a Stand Alone Solar-Wind Based Hybrid Energy System for Application in Ethiopia. Applied Energy, 87:487-495.

Duffie, A. J \& Beckman, A.W. 1980. Solar Engineering of Thermal Processes, Wiley and Sons Inc., New York, pp. 68-76.

Ethiopian Electric Power Corporation (EEPCo.) 2010. Northern Region Distribution Systems, Universal Electricity Access Program customer power demand and network diagrams (unpubl.).

Kudish, A. I \& Ianetz, A. 1996. Analysis of Daily Clearness Index, Global and Beam Radiation for Beer Sheva, Israel: Partition According to Day Type and Statistical Analysis. Energy Conversion and Management, 37(4):405-416. 
Alfa Hailemariam, A., Mulu Bayray, K and Cuthbert Z.M. K (MEJS) Volume 5(2):62-80, 2013

Mulu Bayray, Anwar Mustefa, Hailay Kiros \& others. 2011. Wind and Solar Energy Resource Assessment in Geba Catchment, North Ethiopia. Annual Report, Department of Mechanical Engineering, Ethiopian Institute of Technology, Mekelle University, Ethiopia, pp. 3-16.

National Meteorological Agency of Ethiopia. 2010. Meteorological Stations data archive (unpubl.).

Neway, A. 1996. Estimation of Solar Radiation Energy of Ethiopia from Sunshine Data. International Journal of Sustainable Energy, 18(2):103-113.

Renewable Energy Academy (RENAC). 2008. Off-grid Power Supply Through Photovoltaics. Berlin, Germany, pp. 16-19.

Solar and Wind Energy Resource Assessment (SWERA). 2007. Solar and Wind Energy Utilization and Project Development Scenarios. Final Report, Ethiopian Rural Energy Promotion and Development Center, Addis Ababa, Ethiopia, p. 3-1 - 3-13.

Welde Ghiorgis, W. 1988. Wind Energy Survey in Ethiopia. Solar and Wind Technology, 5(4):341-351, 1988.

Yakob, M \& Frances, D. 1996. Assessment of Wind and Solar Energy in Ethiopia. Solar energy, 57(4):323-334. 
Alfa Hailemariam, A., Mulu Bayray, K and Cuthbert Z.M. K(MEJS) Volume 5(2):62-80, 2013

Annexure.1. Sample worksheet for solar resource calculations of Serawat.

\begin{tabular}{|c|c|c|c|c|c|c|c|c|c|c|c|c|c|}
\hline $\begin{array}{l}\text { Site } \\
\text { Name }\end{array}$ & Parameter & 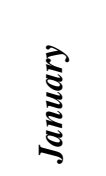 & 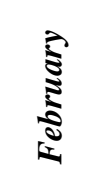 & $\frac{\sqrt{3}}{2}$ & $\frac{\sqrt{4}}{\sqrt[5]{2}}$ & हे & $\underset{\mathfrak{z}}{\mathfrak{z}}$ & $\vec{\Xi}$ & $\frac{\sqrt{1}}{3}$ & 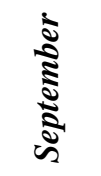 & $\frac{5}{0}$ & $\begin{array}{l}\grave{\Xi} \\
\vdots \\
\vdots \\
\vdots \\
\vdots\end{array}$ & 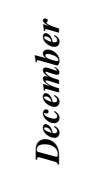 \\
\hline \multirow{10}{*}{$\begin{array}{l}\text { Serawat } \\
\Phi=13.47 \\
\mathrm{E}_{0}=2.22\end{array}$} & $\begin{array}{l}\text { Average sunshine } \\
\text { hours } \mathrm{n} \text { from Table } 3\end{array}$ & 9.9 & 10.1 & 9.6 & 9.7 & 10.1 & 7.9 & 5.0 & 5.4 & 7.8 & 10.0 & 10.1 & 10.1 \\
\hline & $\begin{array}{l}\text { The day length of the } \\
\text { average day of the } \\
\text { month } N \text { (hours) } \\
\text { Figure 2 }\end{array}$ & 11.31 & 11.58 & 11.93 & 12.31 & 12.63 & 12.79 & 12.72 & 12.45 & 12.08 & 11.70 & 11.38 & 11.23 \\
\hline & $\begin{array}{l}\text { The percent possible } \\
\text { sun shine }\left(\frac{n}{N}\right)\end{array}$ & 0.87 & 0.87 & 0.80 & 0.79 & 0.80 & 0.62 & 0.40 & 0.43 & 0.65 & 0.86 & 0.89 & 0.90 \\
\hline & $\begin{array}{l}\text { Inclination angle for } \\
\text { the average day of the } \\
\text { month } \delta \text { (Degrees) }\end{array}$ & -20.9 & -13.0 & -2.4 & 9.4 & 18.8 & 23.1 & 21.2 & 13.5 & 2.2 & -9.6 & -18.9 & -23.0 \\
\hline & \multirow{2}{*}{\begin{tabular}{l|l} 
Coefficients & $\mathrm{a}$ \\
A\& b are & \\
$\begin{array}{l}\text { calculated from } \\
\text { Equation } 3 \& 4\end{array}$ & $\mathrm{~b}$ \\
\end{tabular}} & 0.31 & 0.31 & 0.29 & 0.29 & 0.29 & 0.24 & 0.18 & 0.19 & 0.25 & 0.31 & 0.32 & 0.32 \\
\hline & & 0.42 & 0.42 & 0.45 & 0.45 & 0.45 & 0.51 & 0.59 & 0.58 & 0.50 & 0.43 & 0.41 & 0.41 \\
\hline & $\begin{array}{l}\text { Average number of the } \\
\text { day in the month }\end{array}$ & 17 & 47 & 75 & 105 & 135 & 162 & 198 & 228 & 258 & 288 & 318 & 344 \\
\hline & Hour angle $\omega_{\mathrm{s}}$ (Degrees) & 84.80 & 86.88 & 89.47 & 92.32 & 94.72 & 95.91 & 95.37 & 93.34 & 90.57 & 87.73 & 85.34 & 84.21 \\
\hline & $\begin{array}{l}\text { Monthly Average daily } \\
\text { extraterrestrial } \\
\text { radiation } \mathrm{H}_{0}\left(\mathrm{kWh} / \mathrm{m}^{2}\right)\end{array}$ & 10.71 & 10.16 & 10.79 & 10.14 & 10.59 & 10.75 & 10.73 & 10.19 & 10.62 & 10.37 & 10.29 & 10.63 \\
\hline & $\begin{array}{l}\text { Monthly Average daily } \\
\text { global radiation, } \mathrm{H}_{\mathrm{G}} \\
\left(\mathrm{kWh} / \mathrm{m}^{2}\right) \text { Equation } 1 . \\
\text { Monthly Average Clear- } \\
\text { ness Index }\left(\mathrm{H}_{\mathrm{G}} / \mathrm{H}_{0}\right)\end{array}$ & 7.14 & 7.11 & 6.98 & 6.84 & 6.75 & 6.23 & 5.03 & 5.34 & 6.49 & 7.01 & 7.10 & 7.13 \\
\hline
\end{tabular}

